\title{
Characterization of key performance parameters in dye sensitized solar cells using a designed experiment
}

\author{
Todd Robert Hamrick \\ West Virginia University
}

Follow this and additional works at: https://researchrepository.wvu.edu/etd

\section{Recommended Citation}

Hamrick, Todd Robert, "Characterization of key performance parameters in dye sensitized solar cells using a designed experiment" (2008). Graduate Theses, Dissertations, and Problem Reports. 1906. https://researchrepository.wvu.edu/etd/1906

This Thesis is protected by copyright and/or related rights. It has been brought to you by the The Research Repository @ WVU with permission from the rights-holder(s). You are free to use this Thesis in any way that is permitted by the copyright and related rights legislation that applies to your use. For other uses you must obtain permission from the rights-holder(s) directly, unless additional rights are indicated by a Creative Commons license in the record and/ or on the work itself. This Thesis has been accepted for inclusion in WVU Graduate Theses, Dissertations, and Problem Reports collection by an authorized administrator of The Research Repository @ WVU. For more information, please contact researchrepository@mail.wvu.edu. 


\title{
CHARACTERIZATION OF KEY PERFORMANCE PARAMETERS IN DYE
} SENSITIZED SOLAR CELLS USING A DESIGNED EXPERIMENT

\author{
by
}

Todd Robert Hamrick

Thesis submitted to the College of Engineering and Mineral Resources

at West Virginia University

in partial fulfillment of the requirements

for the degree of

Master of Science

in

Mechanical Engineering

Approved by

James Smith, Ph.D, Committee Chairperson

Darren Cairns, Ph.D.

Majid Jaraiedi, Ph.D.

Roy Nutter, Ph.D

Department of Mechanical and Aerospace Engineering

Morgantown, West Virginia

2008

Keywords: Dye Sensitized Solar Cell, Designed Experiment, Regression 


\begin{abstract}
CHARACTERIZATION OF KEY PERFORMANCE PARAMETERS IN DYE SENSITIZED SOLAR CELLS USING A DESIGNED EXPERIMENT
\end{abstract}

\author{
Todd Robert Hamrick
}

Inorganic photovoltaic cells have been in production for many years, but the silicon production process is expensive, so solar technology is cost prohibitive for all but niche markets. A more cost effective alternative would open usage of solar power production to more applications and make the cost to produce electricity more affordable. Inorganic solar cells could potentially be the lower cost alternative to conventional solar technology, but efficiency and durability are still not high enough for successful competition.

Other research has investigated how to improve individual aspects of dye sensitized solar cells. This work evaluated six primary factors of material and fabrication methods. Both the main factors and their two-level interactions were considered using designed experiments and regression analysis to evaluate which impacted maximum power production to the greatest extent. The experiment determined that three factors were of the greatest importance; use of catalyst, method of application of semi-conductive layer, and temperature. No two-level interactions were determined to be of statistical significance. 


\section{Acknowledgements}

A work of this magnitude requires the input and efforts of many hands. I would like to thank the people who made this possible.

First and foremost are my wife, Debbie, and my kids, Scott and Caroline. They have been my rock and foundation, and it is to these three that this work is dedicated.

My parents are the most generous people on earth, and without their support I could not have begun or continued the efforts required to complete this type of endeavor. The debt of gratitude that I owe them can never be repaid.

I would like to thank Dr. James Smith for his constant and unwavering support. I would like to thank Dr. Darren Cairns for the use of his labs and chemicals. I would also like to thank Dr. Majid Jaraiedi for his generosity with the statistical analysis. I was pleased to be in the trenches with Aaron Kessman and Michelle Neustein, who were both enormously helpful from advice on mixing of sol-gels to use of equipment for which I lacked the training. Franz (Andy) Pertl was generous with electrical circuitry advice. And to all those who offered advice and encouragement, I am much obliged. Thank you one and all. 


\section{Table of Contents}

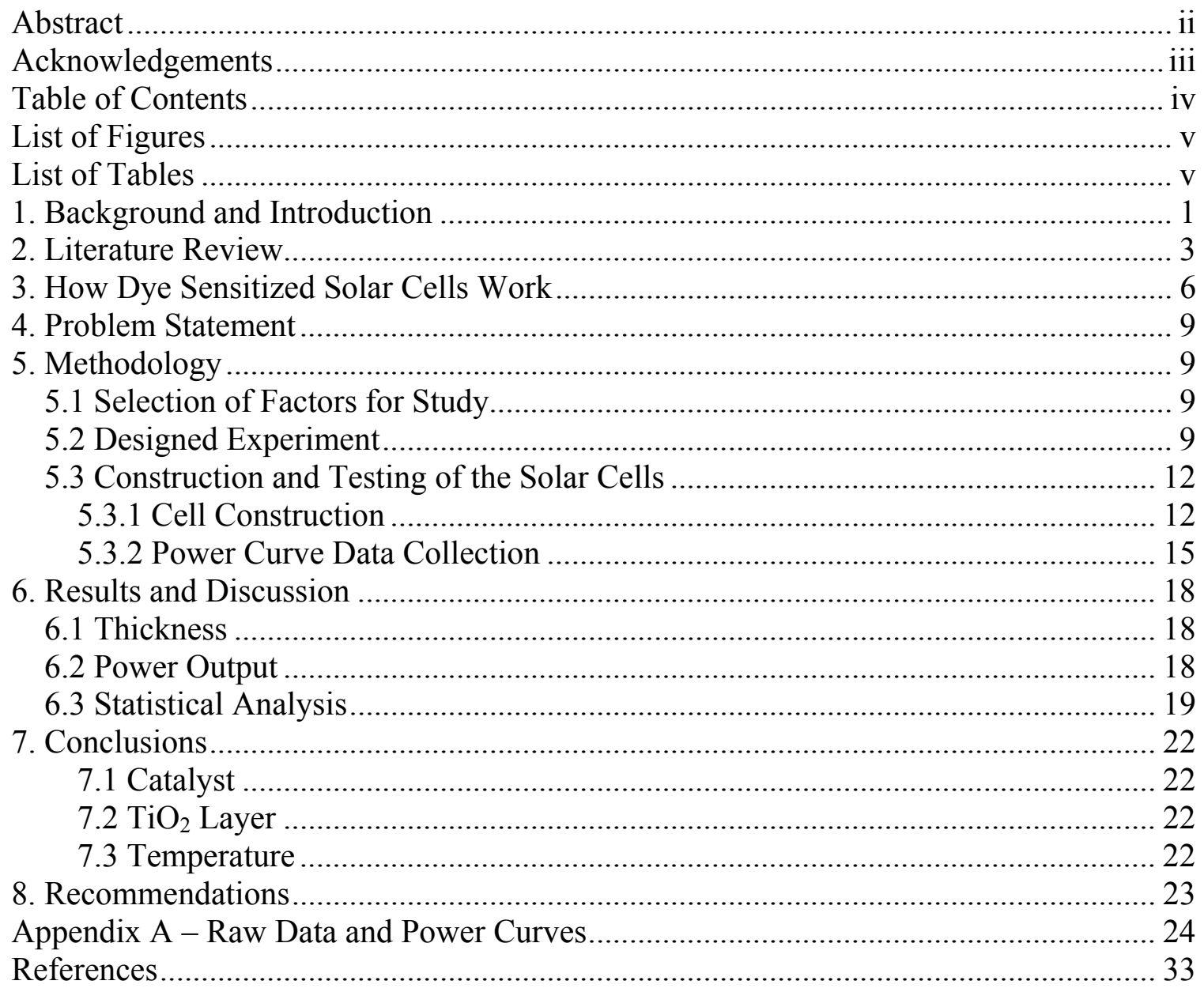




\section{List of Figures}

Figure 1 Schematic Showing the Function of Dye Sensitized Solar Cells ......................... 7

Figure 2 Molecular Representation of Dye................................................................... 8

Figure 3 Cathode on Right Ready for Application of Paste, On Left After Removal of

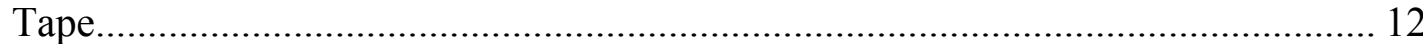

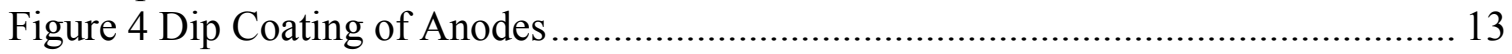

Figure 5 Application of Graphite Catalyst to Anode ..................................................... 14

Figure 6 Assembly of Cells.................................................................................... 14

Figure 7 Cell in Light Box with Leads to Circuit ........................................................... 15

Figure 8 Circuit Layout for Power Data Collection...................................................... 16

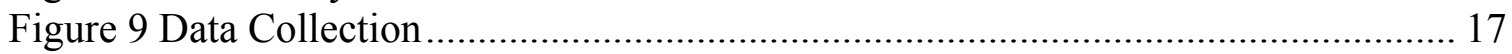

\section{List of Tables}

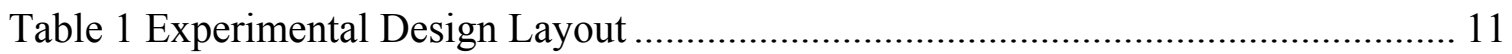

Table 2 Measured Mean Thicknesses of Semi-conducting Layer ................................... 18

Table 3 Maximum Output of All Cells ....................................................................... 19

Table 4 ANOVA for the Designed Experiment............................................................... 20

Table 5 F-Test Values Extracted From ANOVA Table ……………………………..... 21

Table 6 Power Output Comparison between $\mathrm{TiO}_{2}$ Application Method and Thickness .. 22 


\section{Background and Introduction}

Production of electricity using photovoltaic cells was initially developed in the early $20^{\text {th }}$ century, and some commercially viable models using silicon technology were created in the 1950's. The energy crisis of the 1970's brought about a renewed interest in the technology, when research was dedicated to making the silicon based photovoltaic cells more robust, efficient and less expensive. ${ }^{2}$ Silicon based solar cells utilize semiconductor technology similar to that for microchip production, and therefore is an expensive production process. Because of the high investment cost, today's solar cells occupy only niche markets for power production. ${ }^{1}$

Organic photovoltaic cells are modeled after energy production found in nature, mimicking the way plants convert sunlight to energy. Such cells promise lower production costs because materials of lower purity can be utilized. Existing low cost production techniques such as gravure printing can also be used for manufacture. In 1991 Michael Grätzel developed a new class of organic photovoltaic cells by using organic dyes to sensitize comparatively inexpensive semiconductors. While researchers have made laboratory samples that are nearly as efficient as conventional cells, this class of photo electrochemical (PEC) cells is not yet commercially viability. ${ }^{1,2}$

Energy efficiency and durability of organic cells has been increasing in the lab, while the cost of silicon based cells has increased due to a worldwide increase in the consumption of hyper-pure silicon. Within a few years commercially viable organic cells are expected to begin replacing silicon based cells due to cost considerations. ${ }^{3}$

Grätzel cells are constructed by first coating conductive glass slides (Indium Tin Oxide ITO coated) with a semiconductor, usually titanium dioxide $\left(\mathrm{TiO}_{2}\right)$. The $\mathrm{TiO}_{2}$ is sintered to affect its crystal structure. A porous structure is desirable because it maximizes the surface area of the semiconductor. The semiconductor layer is then treated with an organic dye. ${ }^{4}$

Finding an efficient organic dye has been the focus of much research. Dyes can be easily extracted from berries, leaves, chlorophyll, or nearly any plant material that contains flavoniods such as anthocyanin. Some highly efficient dyes have been developed and are commercially available. Most are ruthenium bipyidyl organic compounds. While they can be purchased, they are currently available only in laboratory quantities and are consequently too expensive for commercialization. ${ }^{5}$

Previous research has been conducted on each of the components of the photo electrochemical cell. Particular emphasis has been given to making more efficient organic dies, with some additional research conducted on improved application of semiconductors. ${ }^{2}$ These studies intensively investigate specific characteristics independently. However, little is known about the interaction of the components. Few if any studies are available that investigate how materials interact with one another, or how production techniques work together with the materials to affect efficiency. 
Research to evaluate relationships of the various components to ascertain how they interact with one another would be beneficial to understanding how best to improve overall efficiency of dye sensitized cells. This will increase understanding of how all of the components work together, and which contribute the most to overall efficiency.

This research evaluates these components and their interactions through the use of a designed experiment. Six factors were evaluated at two levels each, including two methods of applying the semi conducting layer at two thicknesses, temperature and time of firing, two different organic dies, and the use of a catalyst. Thirty two cells were manufactured, each unique, according to a specific plan. Each was exposed to a uniform light source, and the maximum power was calculated based on voltage and resistance measured. Statistical analysis was used to determine which factors were the most significant and by how much. 


\section{Literature Review}

Photovoltaic phenomena were first observed in the $19^{\text {th }}$ century. Practical photovoltaic devices were developed in the 1950's using inorganic materials, and almost all production photovoltaics manufactured today are inorganic based silicon. Some organic materials were found to have photovoltaic properties as early as 1906, with polymers recognized as potential for PV cells in the 1950's. Following the energy crisis of the 1970 's a great deal of research was pursued to find alternative energy sources, including "solar harvesting." While efficiencies and production costs for inorganic photovoltaics have improved to the point that they are commercially viable, they are still too costly for all but niche markets. Despite a great deal of research, organic photovoltaics have yet to become practical. ${ }^{2}$

Organic photovoltaics are attractive because they are potentially less expensive to manufacture on a large scale. Not only are the materials generally less expensive than silicon, they are more varied, more available, and high volume processing is very cheap. Organic photovoltaics have the potential to make solar harvesting a cost effective energy solution.

In Polymeric devices, perfect contact between metal electrodes and polymeric materials is not possible. ${ }^{6}$ A thin insulating layer often builds up, causing the device to lose efficiency quickly. A protective layer can be effective in improving the useful life of the device, but more work is required to make this technology viable. ${ }^{7}$

Most of the early research efforts regarding polymer photovoltaics centered on finding materials that were suitable for Photovoltaic processes. Many materials were studied including dyes and even chlorophyll. ${ }^{8}$ CW Tang of the Eastman Kodak Research Facilities in Rochester, NY carried out extensive tests on Photovoltaic devices using Chlorophyll extracted from green spinach. ${ }^{9}$

Tang made an important breakthrough while conducting additional research in 1979, which was published in 1986 . He made use of a concept called heterojunction, where two different materials with different electron affinities and ionization potentials are used together. Devices using two materials are more efficient than those using one, and heterojunction has been the source of a great deal of research in the past two decades. ${ }^{10}$

Dye sensitized solar cells represent a separate class of photovoltaic devices, and are modeled after the way in which plants generate energy. The invention was the brainchild of Michael Grätzel of the Ecole polytechnique fédérale (Federal Polytechnic Institute) de Lausanne, Switzerland. In 1991 he found that sintered colloidal titanium dioxide particles could be dyed with organic chromophores, and the resulting construction constituted a device capable of producing electricity. He had created an artificial leaf. ${ }^{11}$

While initial indications showed great promise, two problems, efficiency and durability, have yet to find effective solutions. Most research into dye sensitized solar cells since 
their invention has focused on the various components of the cells independently. These include organic dyes, electrolytic carriers, counter electrodes, and semi-conductors. As early as 1992 Grätzel and others were searching for improvements in all of these.

Juices extracted from fruit were found to make good dyes for sensitizing the semiconductive layer. Blackberries were soon found to be an excellent choice, as the anthocyanins bonded readily with crystalline titanium dioxide. ${ }^{12}$ Other fruit juices were found to work well, as long as the anthocyanins chelate to the substrate. These include berry juice, pomegranate juice, and teas made from green citrus leaves, hibiscus leaves, or onion skins to name a few. ${ }^{13,4}$ While cells made from these will produce electricity, efficiencies and durability are too low to be practical.

Ruthenium based organic complex dyes were developed by Grätzel and others as early as 1992. ${ }^{14,15,16}$ Collectively known as N-type dyes, these dyes have been the standard for this class of cells for many years, and some are commercially available for purchase. Additional research has improved the performance of $\mathrm{N}$-type dyes by changing chemical structures to form a broader band response to incoming light. ${ }^{17,18,19}$ Some have also made use of the heterojunction principle by mixing dyes, and these have been found to be more efficient than single dyes. ${ }^{20,21}$

Research on electrolytic carrier solutions has been less intense since Grätzel used an iodide solution in his early research. ${ }^{22,23}$ While other electrolyte solutions have been studied with varying success, use of any liquid poses problems. ${ }^{23}$ A liquid sealed permanently inside the cell poses manufacturing issues, and outdoor exposure of liquid filled cells to low temperatures causes shortened life. A dry or "solid state" cell is therefore considered far more practical, and has been the greatest focus of research.

An efficient solid state electrolyte has yet to be developed. Work in this area focuses on elastomers, polymers, and mixtures. ${ }^{24,25,26,27}$ Using gel polymers, a "quasi-solid state" solar cell has been created that shows great promise, and may be the key to making a practical dye sensitized solar cell. ${ }^{28,29,30}$

Some counter electrode work has also been carried out, although this has been an area of secondary concern. Some of the research is dedicated to improving the original carbon coating electrode used by Grätzel. ${ }^{31,32}$ More efficient, although probably not economically practical, have been counter electrodes produced by various applications of platinum.

A great deal of research has been dedicated to the semi-conducting layer. Grätzel started with titanium dioxide, and this is still the standard for dye sensitized solar cells, although other metal oxides including zinc, tin, aluminum and others have been used with success. Many methods of deposition of metal oxides have also been studied including paste applications, dip coating, spin coating, electro-deposition, spray coating and sputtering. 4, 41,35 The method of application seems to matter less than the available surface area, so thin films are possible using some of these techniques. The most efficient dye sensitized cells achieve efficiencies over $10 \%$, but have not yet been successfully scaled up for 
production. ${ }^{36}$ A recent Chinese design has sought to make a workable production design. $^{37}$

Some work has been conducted on the importance of the combination of factors in the construction of cells. Researchers in Japan found that dies properly linked to the titanium dioxide nanostructure produced improved open circuit voltage, thereby increasing power potential. $^{38}$ While some of these interactions are known, no major studies have investigated all of the factors and their interactions. No one has considered how the materials and methods of manufacture can work together to determine which is the optimum combination. A study of primary factors and interactions between then can be accomplished through the use of a designed experiment.

Designed experiments are superior to conventional one-factor-at-a-time experimentation, and have several advantages. They require fewer resources, requiring fewer data points for a complete study. Estimates of the effects are more precise because more data points are used to calculate effects, thereby reducing variability. Most importantly for this study, interactions between factors can be estimated more easily and precisely. This provides for improved estimates of optimum combinations. ${ }^{39}$

A designed experiment is done in two related parts, selection of the experimental design and selection of the statistical analysis. The experimental design takes into account such issues as how many factors will be studied and at how many levels, what will be varied and what will be held constant, and what will be measured as the response variable. Many designs are possible depending on these factors among others. ${ }^{42}$

Statistical analysis can be conducted in many ways, but a widely accepted method is the use of analysis of variance (ANOVA). This analysis defines the overall variability in the data and compares it with the variability in each set of treatments. By analyzing the difference in the variability, it is possible to determine which of the factors or combinations of factors are statistically significant. ${ }^{42}$

Regression analysis is a powerful tool in statistical analysis. This method of analysis quantifies the results by equating the output response to the sum of all of the studied factors or combination of factors, each with a coefficient as seen in Equation 1. The coefficients are mathematically estimated based on the least squares fit of the data. The result is a model that equates the output response to the inputs. This allows for a quantified prediction of output responses from given inputs, and provides information about which inputs have the greatest response. ${ }^{42}$

$y=\beta_{0}+\beta_{1} x_{1}+\bullet \bullet \bullet+\beta_{n} x_{n}+\beta_{n+1} x_{1} x_{2}+\bullet \bullet+\beta_{z} x_{n} x_{m}+\varepsilon$

\section{Equation 1}




\section{How Dye Sensitized Solar Cells Work}

The basic layout of the dye sensitized solar cell can be seen in Figure 1. Two glass plates with conductive clear coating, usually Indium Tin Oxide (ITO) are used. Only one side of the glass is coated, so care must be taken to use the conductive side, which can easily be found by testing the resistivity with a multimeter. The coated side shows measurable resistance, while the uncoated side has infinite resistance.

A layer of semi-conductor is applied to one of the plates, making the cathode of the cell. Titanium dioxide $\left(\mathrm{TiO}_{2}\right)$ is used often, as this material is widely available and inexpensive. The application can be done in a number of ways and at thicknesses up to $0.5 \mathrm{~mm}$. This layer is then fired or sintered in such a way as to cause the $\mathrm{TiO}_{2}$ to form crystals. An organic dye is applied to the cooled semi-conducting layer and allowed to dry. To create the anode, a layer of graphite is applied to the other glass plate, which serves to improve conductivity of that plate and as a catalyst for the electrochemical process. The plates are then put face-to-face with a liquid electrolytic solution between them. This is often an iodine/iodide solution, which readily exchanges electrons. 


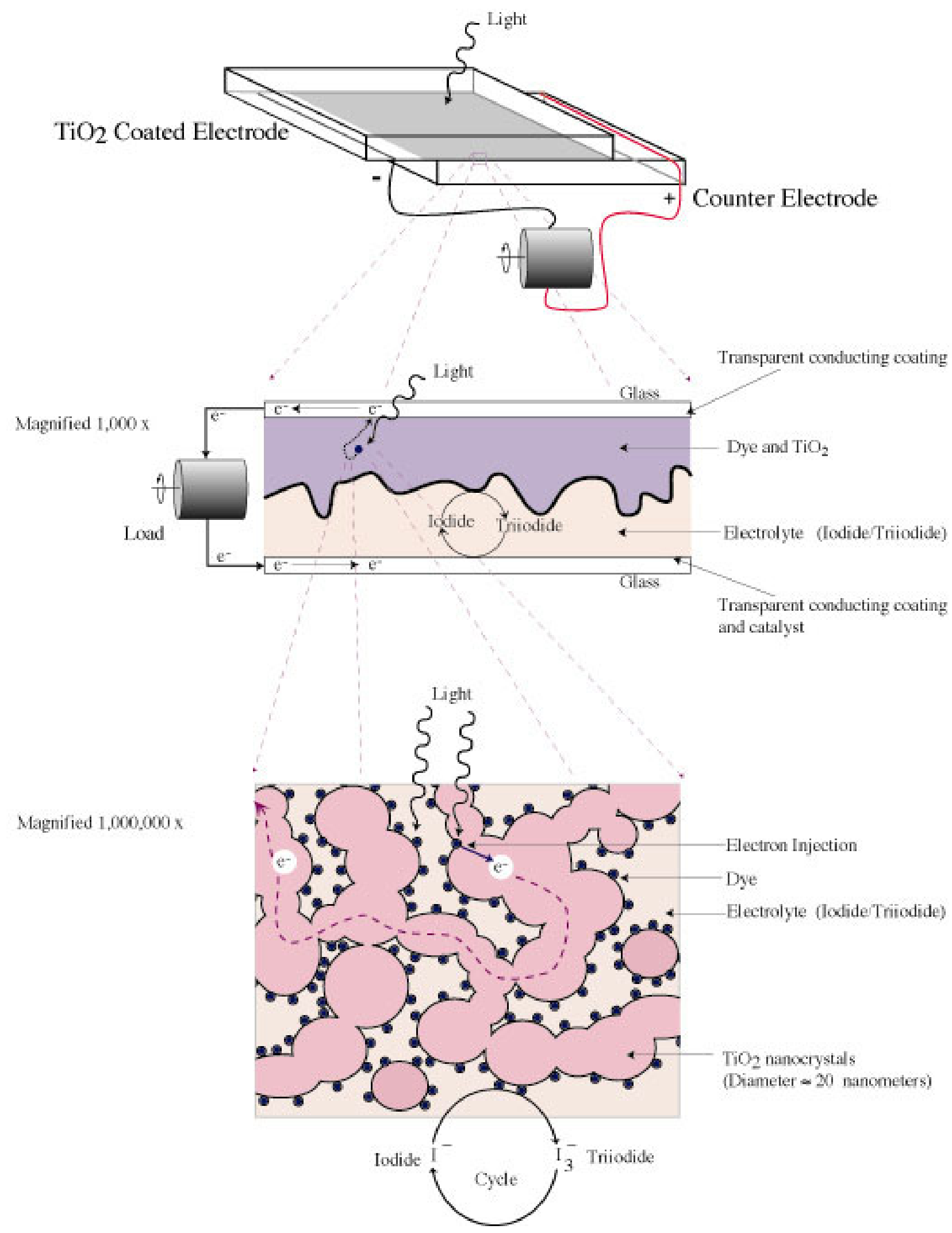

Figure 1 Schematic Showing the Function of Dye Sensitized Solar Cells ${ }^{4}$ 
The dye molecules are chemically attached to the semi-conductive material. They do this by linking a complex sugar group known as Cyanin to one of the oxygen molecules in the $\mathrm{TiO} 2$ crystal structure, as can be seen in Figure 2.

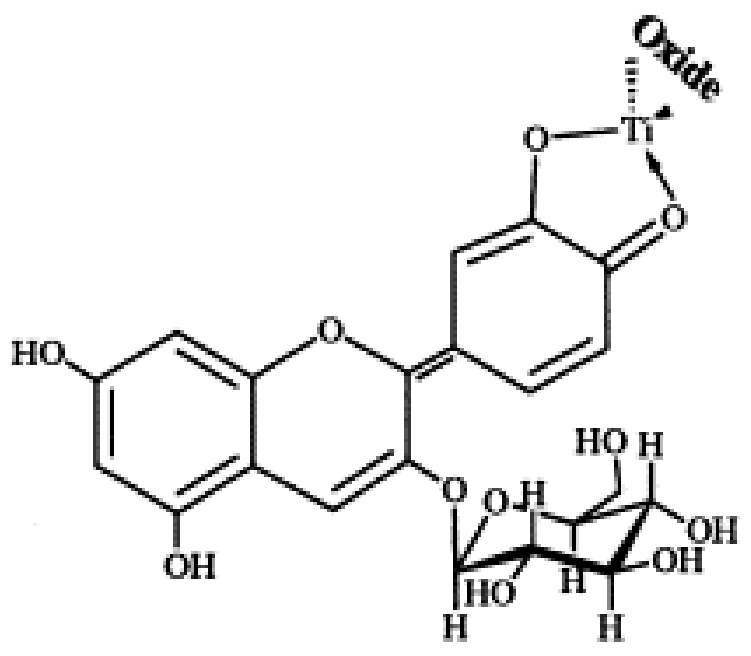

Figure 2 Molecular Representation of Dye

Attached to Titanium Dioxide Structure ${ }^{4}$

When a photon from the light source strikes the dye, electrons in the dye become excited and are released into the semiconductor. From there they are free to flow through the semiconductor to the glass plate and out to the circuit. Once completing the circuit, they flow back to the anode, where the conductive graphite allows free flow of the electrons back through the electrolyte solution to the original site of the lost electron in the dye. $4,40,41$ 


\section{Problem Statement}

Using a designed experiment, analysis of variance and regression analysis, identify the primary factors and their interactions affecting power generation in dye sensitized solar cells and the degree to which they impact the output.

\section{Methodology}

\subsection{Selection of Factors for Study}

There are many different materials that can be used to make dye sensitized solar cells, and many different methods for manufacturing them. It is beyond the scope of this study to evaluate all of them. For this study, six factors were selected for evaluation; Application of Semi-conducting layer, thickness, sintering temperature, sintering time, dye type, and use of catalyst.

The semi-conducting layer is the focus of much research in the literature, and for that reason it was the primary focus of study in this work. Four of the six factors selected examine its application and treatment. Dye type and use of catalyst add extra dimensions to the study by evaluating how these factors affect power when combined with the four treatments of the semi-conducting layer. While it is impractical to study all possible combinations of materials and methods, this selection covers a wide range of the most common. This study evaluates six factors at two levels each, which provides an effective screening experiment to determine what the most important factors are to produce the greatest power.

\subsection{Designed Experiment}

The most thorough and organized approach to evaluating multiple factors and their interactions is through the use of a designed experiment. Six factors at two levels create a $2^{6}$ factorial designed experiment. In order to reduce the number of cells that were to be created, the $2{ }_{\mathrm{IV}}{ }^{6-1}$ half fraction factorial experimental design was followed, which requires the manufacture of 32 unique cells. Equation 2 represents the linear statistical model for this experiment.

$$
\begin{aligned}
& Y_{i j k l m n}=\mu+\alpha_{i}+\beta_{j}+\gamma_{k}+\tau_{l}+v_{m}+\omega_{n}+(\alpha \beta)_{i j}+(\alpha \gamma)_{i k}+\bullet \bullet \bullet+(v \omega)_{m n}+\varepsilon_{i j k l m n} \quad \text { Equation } 2 \\
& \text { where } i=1,2 \quad j=1,2 \quad k=1,2 \quad l=1,2 \quad m=1,2 \quad n=1,2
\end{aligned}
$$


The design layout for this experiment can be seen in Table 1. The run number was selected according to the standard method known as Yates' Order, and is the standard for designed experiments. ${ }^{42}$ Two levels of each factor were selected for evaluation. The + indicates the factor at a high level, and the - indicates the factor at a low level. The application method of the $\mathrm{TiO}_{2}$ layer and the dye type were arbitrarily selected as + and levels. The lower case letters in the "Level" column indicate that the factor will be at its high level for that run, and all others will be at their low level. The (1) indicates that all factors will be at their low levels for that run. The 32 runs were done in a random order, as is required by the assumption of the linear statistical model.

The purpose for the designed experiment is to provide information about all of the factors tested. The factors most significant to the desired outcome can be determined, as well those that are of less importance. It will also provide information about some interactions between the factors. If a particular set of factor settings work better in combination, the designed experiment will indicate them.

Some interaction information may be lost in the process unless all of the possible combinations of factors are produced. Since this is impractical, the organized method of designing the experiment manages the loss of interaction detail. This is done through specifying the "confounding" rules rather than leaving them to chance. Confounding means that the experiment will be unable to determine the cause of any statistically significant difference between the results. Because they may look the same, they are said to be "aliased." By designing the experiment, the researcher assumes that individual factors will contribute the most to the final results, that two factor (second order) interactions will be of lesser import, and that impact to the results will be of lesser gravity as the order of interaction increases. For this experiment, only two factor interactions were considered, as higher order interactions are less likely to contribute significantly to the final results. ${ }^{42}$ 
Table 1 Experimental Design Layout

\begin{tabular}{|c|c|c|c|c|c|c|c|}
\hline Run & Level & $A$ & $B$ & C & $\mathrm{D}$ & $E$ & $\mathrm{~F}=\mathrm{ABCDE}$ \\
\hline 1 & $(1)$ & - & - & - & - & - & - \\
\hline 2 & a & + & - & - & - & - & + \\
\hline 3 & $\mathrm{~b}$ & - & + & - & - & - & + \\
\hline 4 & $a b$ & + & + & - & - & - & - \\
\hline 5 & $\mathrm{C}$ & - & - & + & - & - & + \\
\hline 6 & $\mathrm{ac}$ & + & - & + & - & - & - \\
\hline 7 & $\mathrm{bc}$ & - & + & + & - & - & - \\
\hline 8 & $a b c$ & + & + & + & - & - & + \\
\hline 9 & $\mathrm{~d}$ & - & - & - & + & - & + \\
\hline 10 & $\mathrm{ad}$ & + & - & - & + & - & - \\
\hline 11 & bd & - & + & - & + & - & - \\
\hline 12 & $a b d$ & + & + & - & + & - & + \\
\hline 13 & $\mathrm{~cd}$ & - & - & + & + & - & - \\
\hline 14 & acd & + & - & + & + & - & + \\
\hline 15 & bcd & - & + & + & + & - & + \\
\hline 16 & abcd & + & + & + & + & - & - \\
\hline 17 & $\mathrm{e}$ & - & - & - & - & + & + \\
\hline 18 & $\mathrm{ae}$ & + & - & - & - & + & - \\
\hline 19 & be & - & + & - & - & + & - \\
\hline 20 & abe & + & + & - & - & + & + \\
\hline 21 & ce & - & - & + & - & + & - \\
\hline 22 & ace & + & - & + & - & + & + \\
\hline 23 & bce & - & + & + & - & + & + \\
\hline 24 & abce & + & + & + & - & + & - \\
\hline 25 & de & - & - & - & + & + & - \\
\hline 26 & ade & + & - & - & + & + & + \\
\hline 27 & bde & - & + & - & + & + & + \\
\hline 28 & abde & + & + & - & + & + & - \\
\hline 29 & cde & - & - & + & + & + & + \\
\hline 30 & acde & + & - & + & + & + & - \\
\hline 31 & bcde & - & + & + & + & + & - \\
\hline 32 & abcde & + & + & + & + & + & + \\
\hline
\end{tabular}

Where the following chart indicates layout criteria

$\begin{array}{llll}\text { A } & \mathrm{TiO}_{2} \text { Layer } & \begin{array}{l}\text { Dip } \\ \text { Coated }\end{array} & \text { Paste } \\ \text { B } & \mathrm{TiO}_{2} \text { Thickness } & \text { Thick } & \text { Thin } \\ \text { C } & \text { Heat Temp } & \text { High } & \text { Low } \\ \text { D } & \text { Heat Time } & \text { Long } & \text { Short } \\ \text { E } & \text { Dye Type } & \text { Blackberry } & \text { Pomegranate } \\ \text { F } & \text { Catalyst } & \text { Yes } & \text { No }\end{array}$




\subsection{Construction and Testing of the Solar Cells}

\subsubsection{Cell Construction}

The cells were constructed by first cutting ITO coated glass into 64 pieces of 1 inch squares using a glass cutter. Half of the cells were segregated for use as anodes and set aside. The remaining plates were divided again, with 16 designated for dip coating and 16 for paste.

Paste was mixed by placing approximately $1 \mathrm{cc}$ of $\mathrm{TiO}_{2}$ powder on a mixing plate. To this was added $0.5 \mathrm{cc}$ of $10 \%$ acetic acid mixed with water. The mixture was kneaded until no lumps of dry powder remained, and a paste was achieved. The conductive side of the plates was found, and to all 16 of them adhesive tape was applied on three sides, making a frame around the edges. To eight of the slides, a second layer of tape was applied, creating a double thickness of tape. This procedure made the high and low thicknesses of the paste samples. The hollow center of each plate was then filled with paste. The paste was smoothed and the excess removed by using a straight edge as a doctor blade with the tape as a guide. The tape was then removed and the samples were ready for firing. Figure 3 is a photo of a cathode ready for paste and another after the paste has been applied and the tape removed.

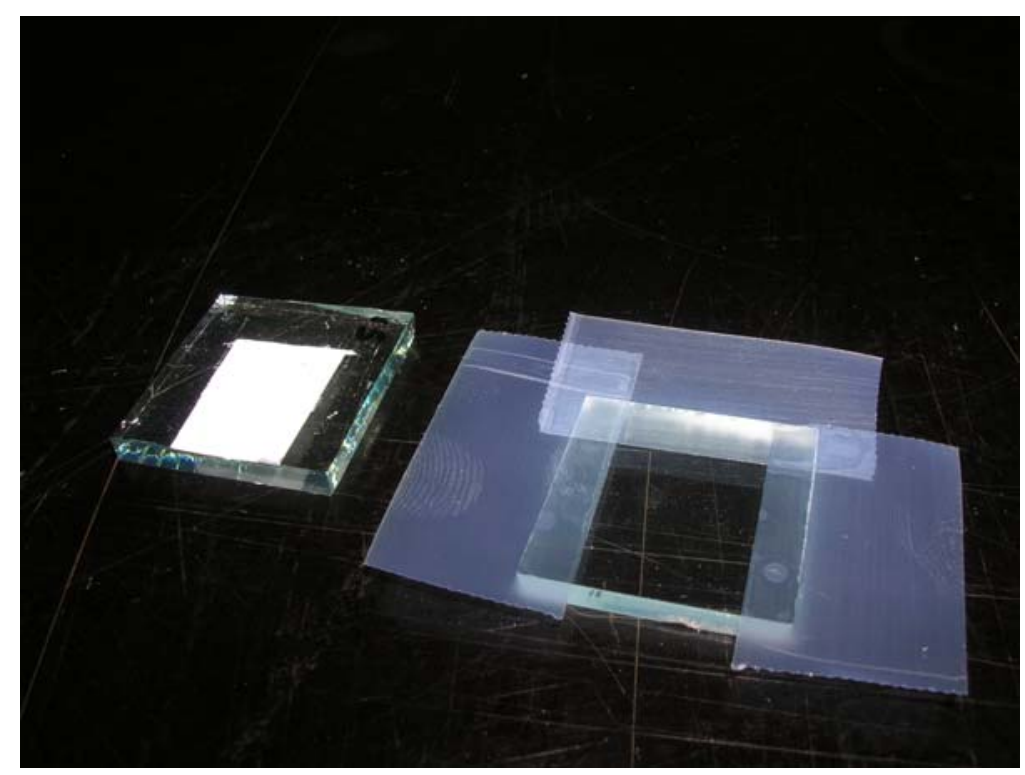

Figure 3 Cathode on Right Ready for Application of Paste, On Left After Removal of Tape

Dip coating was mixed by adding 5.22 g Titanium Butoxide to $21.2 \mathrm{~g}$ Ethanol and $1.84 \mathrm{~g}$ of acetic acid. The mixture was allowed to mix for two hours at medium speed. At that point $21.2 \mathrm{~g}$ of Ethanol was added, along with $0.55 \mathrm{~g}$ of water added drop wise. This was allowed to stir for 16-20 hours, after which a white liquid was present. All 16 of the 
plates were dipped at an extraction speed of $200 \mathrm{~mm} / \mathrm{sec}$, as seen in Figure 4. Eight of these represented the low thickness of the dip coated samples. All were allowed to air dry, and eight were dipped a second time at the same speed to make the high thickness level samples. These were then ready for firing.

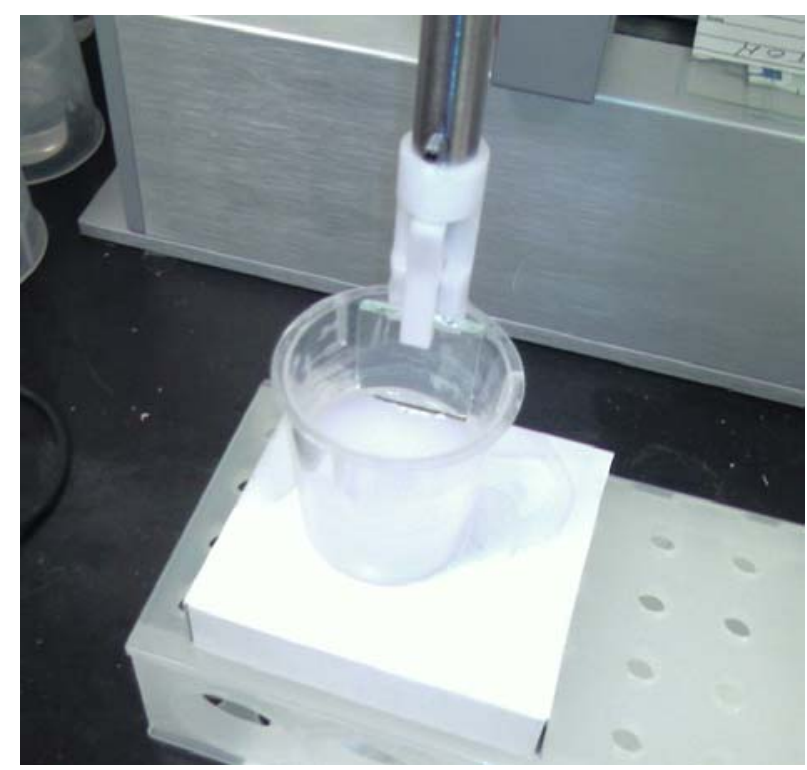

Figure 4 Dip Coating of Anodes

Firing was done by pre-heating an oven to $300^{\circ} \mathrm{C}$. Samples to be fired at that temperature were placed in the oven and allowed to soak for the appropriate time, ten or thirty minutes depending on the requirement from Table 1 . The high temperature samples were prepared in the same way according to the table, but with the oven set at $450^{\circ} \mathrm{C}$. At this point the samples were numbered so that they could be identified.

Dye was prepared by simply extracting juice from fruit. The berry juice was simply squeezed from California Blackberries, and $100 \%$ pomegranate juice from concentrate was purchased. Dyes were applied to the semi-conductor according to the table and allowed to dry. Just enough dye was applied to stain the semiconductor, usually three or four drops. Graphite was applied to the appropriate samples as seen in Figure 5 according to the schedule. 


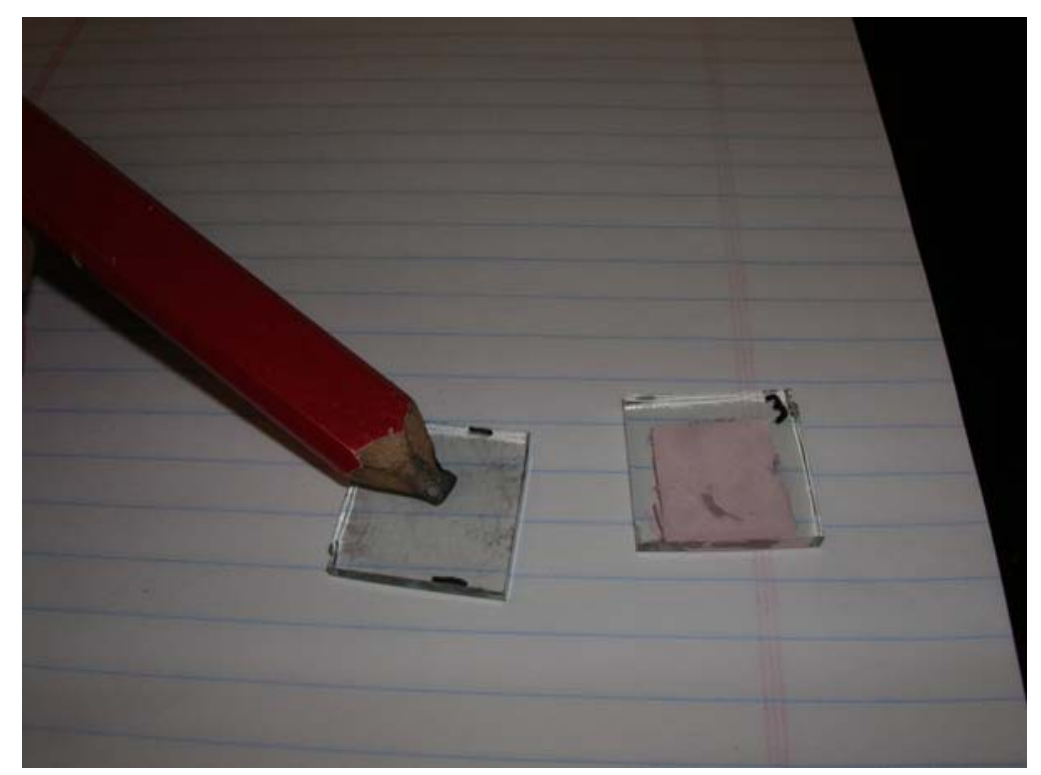

Figure 5 Application of Graphite Catalyst to Anode

Iodide solution was made by mixing 0.5 moles of potassium iodide with 0.05 moles of water-free ethylene glycol. Three drops were applied to one of the plates, and they were then put together. Once clamped the solar cells were ready for testing. This assembly process can be seen in Figure 6. Note that the binder clips serve as clamps, and are not used for electrical conduction.

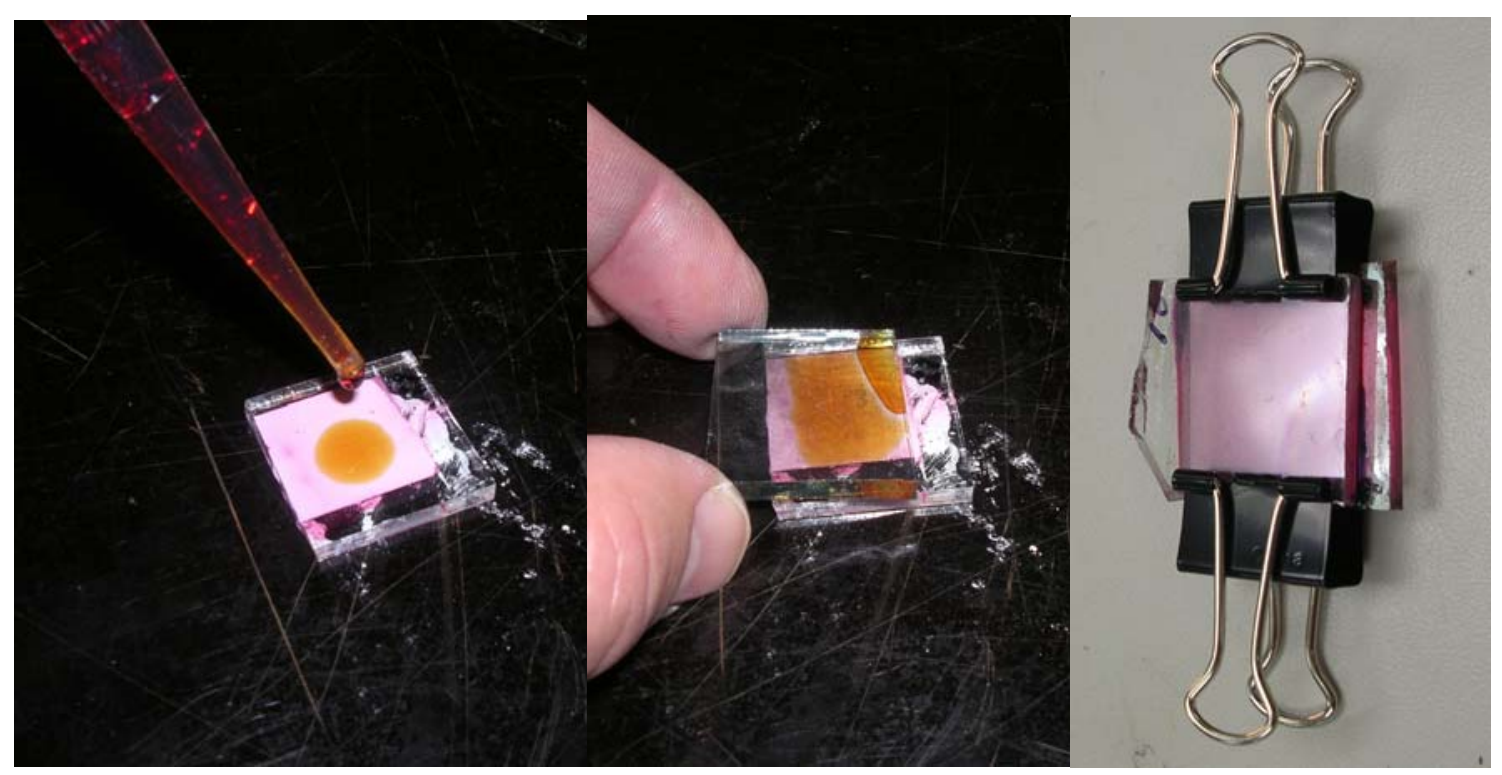

Figure 6 Assembly of Cells 


\subsubsection{Power Curve Data Collection}

Open Circuit Voltage and Power data were taken immediately upon construction of each sample cell. Samples were placed in a light box with direct exposure to a standard 70 watt electric light bulb at a distance of approximately four inches, as seen in Figure 7. The interior of the box was painted white so that all surfaces would reflect back to the cell. Leads with alligator clips were used to connect the solar cells, with one on the anode and another on the cathode.

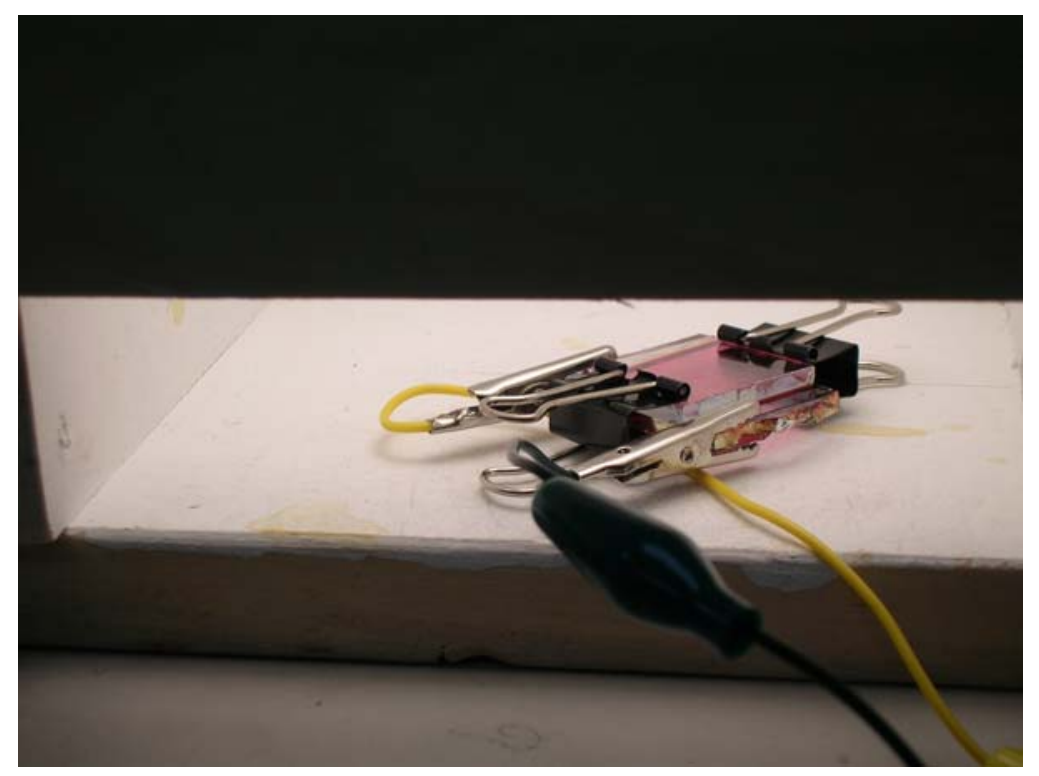

Figure 7 Cell in Light Box with Leads to Circuit

In order to collect the appropriate data, the dual mode circuit in Figure 8 was created because two measurements must be taken for each data point. For each data point, both the resistance and voltage must be measured, where power is calculated according to Equation 3. A photo showing the set-up is provided in Figure 9. 


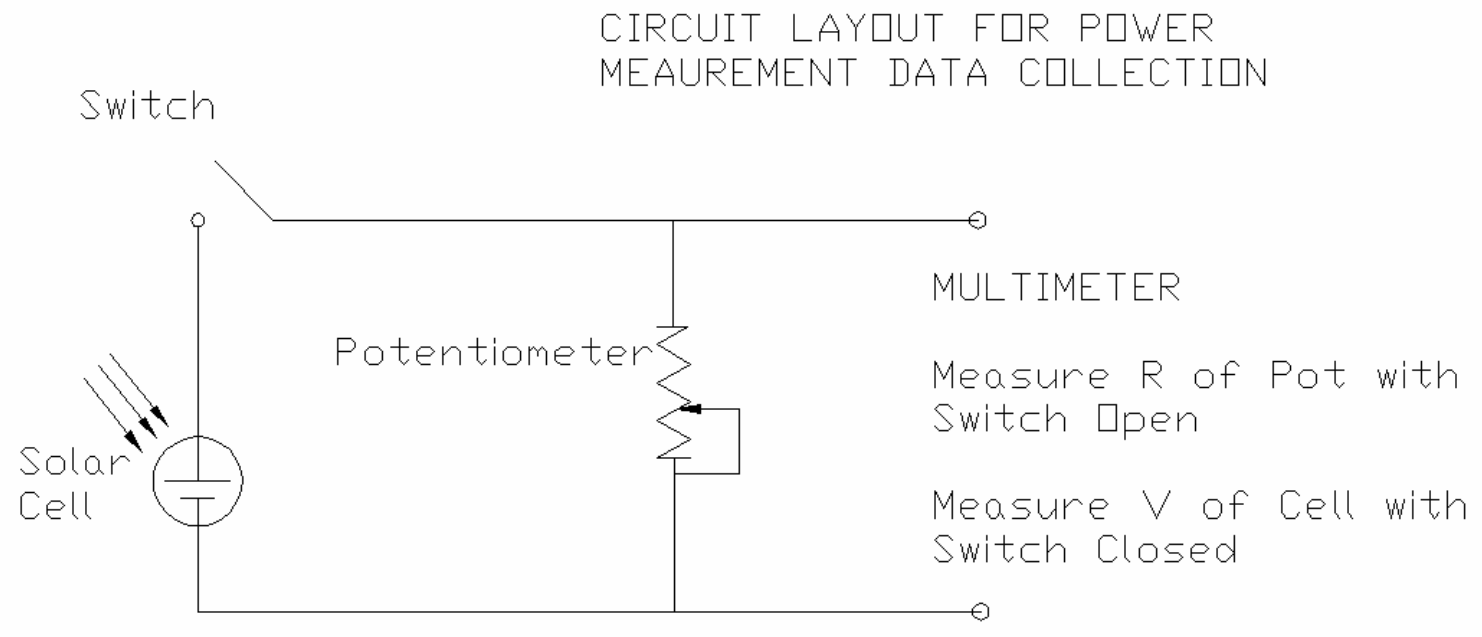

Figure 8 Circuit Layout for Power Data Collection

$P=\frac{V^{2}}{R}$,

where

$P=$ Power (Watts),

Equation 3

$V=$ Voltage (Volts),

$R=$ Resistance $(\mathrm{Ohms})$. 
The circuit was used by first closing the switch and setting the potentiometer to the lowest level that still produced a measurable voltage drop across the resistance. This voltage was measured by a multimeter, the value was recorded and the switch was opened. The resistance of the potentiometer was also measured by the multimeter. The switch was closed, the multimeter reset to measure voltage, and the potentiometer was moved until the voltage drop reading changed. This process was repeated until the power level no longer increased, at which point a maximum had been reached.

Samples must be made and tested in a random fashion to randomize error. The samples were randomized, and the order of testing was as follows: $23,19,27,25,31,29,17,21$, $18,24,30,26,20,32,22,28,13,2,8,12,3,16,14,5,6,4,10,9,11,1,7$, and 15 .

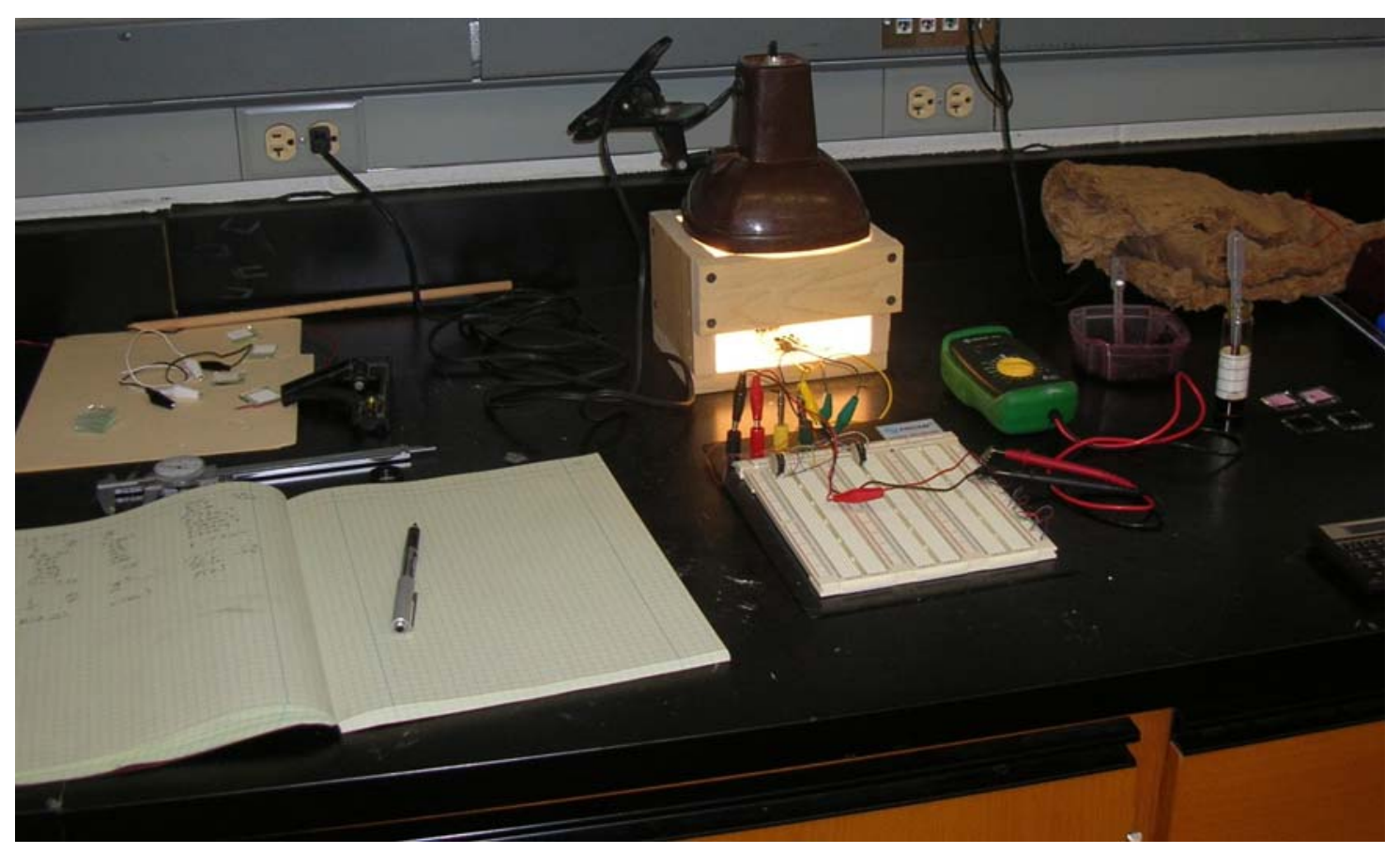

Figure 9 Data Collection 


\section{Results and Discussion}

\subsection{Thickness}

Using these application methods, it was not possible to control the precise thickness of the $\mathrm{TiO}_{2}$ layer at the time of application. In order to determine the thickness, it was measured after firing. Using a Profilometer (Veeco Dektak 150), thicknesses of representative samples were measured. The thicknesses are reported in Table 2.

Table 2 Measured Mean Thicknesses of Semi-conducting Layer

\begin{tabular}{|l|l|}
\hline Cell Configuration & Thickness \\
\hline Dip Coated, Thin Layer & $140 \mathrm{~nm}$ \\
\hline Dip Coated, Thick Layer & $270 \mathrm{~nm}$ \\
\hline Paste Applied, Thin Layer & $55 \mu \mathrm{m}$ \\
\hline Paste Applied, Thick Layer & $86 \mu \mathrm{m}$ \\
\hline
\end{tabular}

The surface of the dip coated samples was quite rough, with particles making large peaks in the profile ranging from 2-500 $\mathrm{nm}$ for the single dipped samples, and 5-1000 $\mathrm{nm}$ on the double dipped samples. The surfaces of the paste applied samples were significantly smoother and more even than the dip coated samples. However, adhesion of the $\mathrm{TiO}_{2}$ particles to the ITO glass was considerably higher on the dip coated samples, as observed on the samples.

\subsection{Power Output}

Power output of the cells was determined by measuring both the resistance of the potentiometer and the voltage drop across it at various increments. Using Equation 3, the power output at each point was calculated, and by systematically increasing resistance of the potentiometer, the maximum power was determined.

Maximum power is reached when the resistive load equals the internal resistance of the solar cell. ${ }^{43}$ The internal resistance in this apparatus includes the contact resistance of the alligator clips to the glass slides. In order to ensure that the clips made a negligible difference to the apparent resistive load, resistivity of the connection was tested separately. Five samples were evaluated two ways, each at a distance of one inch between the connectors. First a 1/16 inch copper rod was inserted between the alligator clip and the conductive side of the glass, and resistance was measured. Next the clips were connected directly to the glass, and the resistance was measured again. The average difference between these was calculated to be $1.44 \mathrm{kOhms}$. Average difference was used 
because the resistivity of the conductive coating is independent of attachment method. The average resistance of all cells at maximum power was $40.84 \mathrm{kOhms}$. The contact resistance was therefore an average of $3.5 \%$ of the apparent internal resistance of the cell, and can be neglected as insignificant.

The area of each cell was measured so that the output could be standardized to a persquare-meter basis. The maximum power output for each cell can be seen in Table 3. The raw data for each cell and its corresponding power curve is presented in Appendix A.

Table 3 Maximum Output of All Cells

\begin{tabular}{|c|c|c|c|c|}
\hline Cell & $\begin{array}{c}\text { Power } \\
\left(\mathrm{mW} / \mathrm{m}^{2}\right)\end{array}$ & Cell & $\begin{array}{c}\text { Power } \\
\left(\mathrm{mW} / \mathrm{m}^{2}\right)\end{array}$ \\
\hline 1 & 0.05 & & 17 & 0.91 \\
\hline 2 & 0.00 & & 18 & 0.00 \\
\hline 3 & 5.13 & & 19 & 0.46 \\
\hline 4 & 0.00 & & 20 & 0.32 \\
\hline 5 & 5.75 & & 21 & 3.93 \\
\hline 6 & 0.75 & & 22 & 3.21 \\
\hline 7 & 0.19 & & 23 & 1.85 \\
\hline 8 & 0.09 & & 24 & 1.25 \\
\hline 9 & 4.72 & & 25 & 0.87 \\
\hline 10 & 0.00 & & 26 & 0.05 \\
\hline 11 & 0.01 & & 27 & 4.41 \\
\hline 12 & 0.08 & & 28 & 0.01 \\
\hline 13 & 1.63 & & 29 & 4.48 \\
\hline 14 & 0.13 & & 30 & 0.54 \\
\hline 15 & 5.39 & & 31 & 0.56 \\
\hline 16 & 0.16 & & 32 & 7.42 \\
\hline
\end{tabular}

\subsection{Statistical Analysis}

The data from Table 3 was input into a Statistical Analysis System (SAS) program capable of quickly and accurately performing the analysis. It was programmed to analyze the six main factors and all two factor interactions. The analysis of variance (ANOVA) is shown in Table 4.

Of particular interest is the statistical significance, which is determined by the F-test. The F-test compares the variance of two sets of data. The value is then compared to a risk value set by the experimenter. The risk value, commonly denoted as alpha $(\alpha)$, was selected to be 0.05 , which is generally considered a reasonable rule of thumb. This means that there is a $5 \%$ chance that a significant difference will be found where none exists. Conversely, there is a $95 \%$ confidence that the statistical significance is real. 
Table 4 ANOVA for the Designed Experiment

ANOVA for Response $Y$

\begin{tabular}{|c|c|c|c|c|c|c|c|c|c|c|}
\hline \multirow[b]{2}{*}{ Source } & \multicolumn{5}{|c|}{ Master Model } & \multicolumn{5}{|c|}{ Predictive Model } \\
\hline & $\mathrm{DF}$ & SS & MS & $\mathrm{F}$ & $\mathrm{Pr}>\mathrm{F}$ & DF & SS & MS & $\mathrm{F}$ & $\mathrm{Pr}>\mathrm{F}$ \\
\hline A & 1 & 21.633 & 21.633 & 6.149 & 0.033 & 1 & 21.632 & 21.632 & 7.579 & 0.010 \\
\hline$B$ & 1 & 0.003 & 0.003 & 0.001 & 0.978 & & & & & \\
\hline C & 1 & 12.909 & 12.909 & 3.669 & 0.084 & 1 & 12.909 & 12.909 & 4.523 & 0.042 \\
\hline $\mathrm{D}$ & 1 & 1.352 & 1.352 & 0.384 & 0.549 & & & & & \\
\hline$E$ & 1 & 1.202 & 1.202 & 0.342 & 0.572 & & & & & \\
\hline $\mathrm{F}$ & 1 & 35.083 & 35.083 & 9.972 & 0.010 & 1 & 35.083 & 35.083 & 12.291 & 0.0012 \\
\hline$A^{*} B$ & 1 & 2.523 & 2.523 & 0.717 & 0.417 & & & & & \\
\hline$A^{*} \mathrm{C}$ & 1 & 1.075 & 1.075 & 0.305 & 0.593 & & & & & \\
\hline$A * D$ & 1 & 0.103 & 0.103 & 0.009 & 0.925 & & & & & \\
\hline$A^{*} E$ & 1 & 9.012 & 9.012 & 2.561 & 0.141 & & & & & \\
\hline$A^{*} F$ & 1 & 8.373 & 8.373 & 2.380 & 0.154 & & & & & \\
\hline $\mathrm{B}^{*} \mathrm{C}$ & 1 & 1.688 & 1.688 & 0.480 & 0.504 & & & & & \\
\hline$B^{*} D$ & 1 & 3.747 & 3.747 & 1.065 & 0.326 & & & & & \\
\hline $\mathrm{B}^{\star} \mathrm{E}$ & 1 & 0.570 & 0.570 & 0.162 & 0.696 & & & & & \\
\hline $\mathrm{B}^{\star} \mathrm{F}$ & 1 & 3.493 & 3.493 & 0.993 & 0.343 & & & & & \\
\hline$C * D$ & 1 & $\begin{array}{r}1.50 \mathrm{E}- \\
05\end{array}$ & $\begin{array}{r}1.50 \mathrm{E}- \\
05\end{array}$ & $\begin{array}{r}4.60 \mathrm{E}- \\
06\end{array}$ & 0.998 & & & & & \\
\hline$C^{*} E$ & 1 & 4.578 & 4.578 & 1.301 & 0.281 & & & & & \\
\hline$C^{*} \mathrm{~F}$ & 1 & 0.804 & 0.804 & 0.228 & 0.643 & & & & & \\
\hline$D^{*} E$ & 1 & 1.224 & 1.224 & 0.347 & 0.568 & & & & & \\
\hline$D^{*} \mathrm{~F}$ & 1 & 4.686 & 4.686 & 1.332 & 0.275 & & & & & \\
\hline$E^{\star} \mathrm{F}$ & 1 & 0.376 & 0.376 & 0.106 & 0.751 & & & & & \\
\hline Model & 21 & 114.361 & 5.446 & 1.548 & 0.241 & 3 & 69.624 & 23.28 & 8.131 & $\begin{array}{r}4.75 \mathrm{E}- \\
04\end{array}$ \\
\hline Error & 10 & 35.181 & 3.518 & & & 28 & 79.918 & 2.854 & & \\
\hline $\begin{array}{l}\text { (Lack of } \\
\text { Fit) }\end{array}$ & & & & & & 4 & 13.605 & 3.401 & 1.231 & 0.324 \\
\hline $\begin{array}{l}\text { (Pure } \\
\text { Error) }\end{array}$ & & & & & & 24 & 66.313 & 2.763 & & \\
\hline Total & 31 & 149.542 & & & & 31 & 149.542 & & & \\
\hline
\end{tabular}


The program determines the target $\mathrm{F}$ distribution, and calculates the $\mathrm{F}$-value for the given data for comparison. If the F-value is greater than the calculated value, then it is outside of the distribution of where it would be expected to fall, and is therefore statistically significant. ${ }^{42}$ Statistical significance was found in three of the main factors and none of the two factor interactions. The F-Test Values from the ANOVA chart can be seen in Table 5 .

Table 5 F-Test Values Extracted From ANOVA Table

\begin{tabular}{|c|c|c|c|}
\hline Factor & Description & F-Master & F-Predictive \\
\hline A & $\mathrm{TiO}_{2}$ Paste/Dip Coating & 6.149 & 7.579 \\
\hline C & Heating Temperature & 3.669 & 4.523 \\
\hline F & Catalyst & 9.972 & 12.291 \\
\hline
\end{tabular}

Regression analysis determines the degree to which these factors impact the final result $(\mathrm{Y})$ and provides a predictive equation for the response. Using the lease squares method for estimating the coefficients in Equation 1, the regression equation in Equation 4 was calculated in coded units.

$$
Y=1.699-0.8222 * A+0.6351 * C+1.047 * F
$$

\section{Equation 4}

A more meaningful equation in terms of natural units is represented in Equation 5. Using this equation, it is possible to predict the estimated maximum power output of any cell from these three parameters.

$E(Y)=-3.301-0.8222 * A+0.0133 * T+1.047 * F$

Where

$A=+1$ for Dip Coat, -1 for Paste

$F=+1$ for Catalyst, -1 for No Catalyst

$T=$ Temperature $\left(\right.$ Valid only between $300^{\circ} \mathrm{C}$ and $\left.450^{\circ} \mathrm{C}\right)$

Equation 5

From the constants in the equation it is possible to infer some information about the relative impact of each of these factors on the results. The catalyst (F) determines the greatest impact to the result, given that the constant associated with that factor has the largest absolute value. It is also important to note that the constant associated with $\mathrm{TiO}_{2}$ layer (A) is negative. This indicates that if a negative value, meaning paste, were used, the resulting power would be higher than if a positive value were used, meaning that paste has a greater impact than dip coating. Higher temperature (C) is less of a factor, although still significant.

The regression analysis provides additional information about the predicted response. Equation 4 produces a value for expected response based solely on these three factors. They have such a significant impact that these three alone account for $46.6 \%$ of the total response. The other 29 factors and interactions contribute the remaining $53.4 \%$ of the variance in the model. 


\section{Conclusions}

The three most important factors contributing to the power output of the cells in this study are the use of catalyst, application method of the $\mathrm{TiO}_{2}$ layer and achieving a high sintering temperature.

\subsection{Catalyst}

Catalyst was either present or absent. Its use provided the single highest contribution to the overall power output. This is apparent by comparing the mean power output of the 16 cells with catalyst at $2.746 \mathrm{~mW} / \mathrm{m}^{2}$ to the mean power output of the 16 cells without catalyst at $0.652 \mathrm{~mW} / \mathrm{m}^{2}$. Finding a more efficient catalyst may provide the most significant improvement to dye sensitized solar cell design.

\section{2 $\mathrm{TiO}_{2}$ Layer}

Two methods of application for the semi-conducting layer were employed, which imparted significantly different surface features and thicknesses. For this reason the thickness factor (B) is not meaningful when comparing between the different application methods. A comparison of mean power output of the eight cells of the separate type and thicknesses can be seen in Table 6 .

Table 6 Power Output Comparison between $\mathrm{TiO}_{2}$ Application Method and Thickness

\begin{tabular}{|l|r|r|r|l|}
\hline & Thin & Thick & Difference & Power \\
\hline Paste & 2.792 & 2.249 & -0.542 & $\mathrm{mV} / \mathrm{m}^{2}$ \\
\hline Dip Coat & 0.586 & 1.167 & 0.580 & $\mathrm{mV} / \mathrm{m}^{2}$ \\
\hline
\end{tabular}

The power output of the thick paste cells was lower than the thin paste cells. However the power output of the thick dip coated cells was higher than their thin counterparts. This is likely because the thickness of the paste cells was significantly higher than the dip coating method, and may have been so high that an insulating layer was created. On the other hand the thin dip coated cells were so thin that there was very little semi-conducting material available for reaction. The thicker dip coated cells had more semi-conductor than the thin ones, and could therefore process more electrons. A thickness between these two values may help to optimize the design.

\subsection{Temperature}

Sintering is required in order to change the crystal structure of $\mathrm{TiO}_{2}$, as un-sintered material chelates poorly with organic dyes. The higher temperature denoted as statistically significant indicates that a temperature near to $450^{\circ} \mathrm{C}$ is required to achieve improved chelation. 


\section{Recommendations}

Three important factors in production of dye sensitized solar cells were identified through the use of a designed experiment and regression analysis. Additional work is required to completely optimize construction of such cells, including refining of values for these factors. Additional factors can also be studied such as different classes of dyes, different types of semi-conductors, and solid state (dry) electrolytes. Additional designed experiments and regression analysis should be used to improve knowledge about these factors. Experiments with more than two levels will be required in order to optimize the design. 


\section{Appendix A - Raw Data and Power Curves}

The following charts show the raw data as collected from the circuit in Figure 8. The resistance and voltages are actual measurements, and the power calculations are based on

Equation 3. Maximum power is the highest level indicated. The length and width of each cell was measured so that all cells could be standardized to a square centimeter basis. The maximum power values were collected to make Table 3. 


\begin{tabular}{|c|c|c|c|c|}
\hline Cell \# & Date & 8-May-08 & & \\
\hline \multirow[t]{17}{*}{1} & Length (in) & 0.751 & Area $\left(\mathrm{cm}^{2}\right)$ & 3.100897 \\
\hline & Width (in) & 0.64 & OCV (Volts) & 0.07 \\
\hline & $\mathrm{R}$ (kOhms) & $\mathrm{V}(\mathrm{mV})$ & Power $\left(\mathrm{W} / \mathrm{m}^{2}\right)$ & $=\left(\mathrm{V}^{2} / \mathrm{R}\right) /$ area $* 1000$ \\
\hline & 7.77 & 1.3 & 7.01E-07 & \\
\hline & 10.98 & 3.9 & $4.47 \mathrm{E}-06$ & \\
\hline & 14.42 & 6.5 & 9.45E-06 & \\
\hline & 21.43 & 10.3 & 1.60E-05 & \\
\hline & 35.5 & 14.6 & 1.94E-05 & \\
\hline & 50.1 & 20.7 & $2.76 \mathrm{E}-05$ & \\
\hline & 72.8 & 27.3 & 3.30E-05 & \\
\hline & 80.1 & 31.7 & $4.05 E-05$ & \\
\hline & 105.4 & 38.9 & 4.63E-05 & \\
\hline & 211 & 47.4 & 3.43E-05 & \\
\hline & & & & \\
\hline & & & & \\
\hline & & & & \\
\hline & & & Max Power & 4.63E-05 \\
\hline
\end{tabular}

\begin{tabular}{|c|c|c|c|c|}
\hline Cell \# & Date & 7-May-08 & & \\
\hline \multirow[t]{5}{*}{2} & Length (in) & 1.045 & Area $\left(\mathrm{cm}^{2}\right)$ & 4.9755384 \\
\hline & Width (in) & 0.738 & OCV (Volts) & 0.01 \\
\hline & $\mathrm{R}$ (kOhms) & $\mathrm{V}(\mathrm{mV})$ & Power $\left(\mathrm{W} / \mathrm{m}^{2}\right)$ & $=\left(\mathrm{V}^{2} / \mathrm{R}\right) /$ area*1000 \\
\hline & 1 & 0 & $0.00 \mathrm{E}+00$ & \\
\hline & Unmeasurable & & & \\
\hline & & & & \\
\hline & & & & \\
\hline & & & & \\
\hline & & & & \\
\hline & & & & \\
\hline & & & & \\
\hline & & & & \\
\hline & & & & \\
\hline & & & & \\
\hline & & & & \\
\hline & & & & \\
\hline & & & Max Power & $0.00 \mathrm{E}+00$ \\
\hline
\end{tabular}

\begin{tabular}{|r|l|r|r|r|}
\hline \multicolumn{1}{|l|}{ Cell \# } & Date & 7-May-08 & & \\
\hline 3 & Length (in) & 0.812 & Area $\left(\mathrm{cm}^{2}\right)$ & 3.7456699 \\
\hline & Width (in) & 0.715 & OCV $($ Volts) & 0.2 \\
\hline & R (kOhms) & V (mV) & Power (W/m $\left.{ }^{2}\right)$ & $=\left(\mathrm{V}^{2} / \mathrm{R}\right) /$ area*1000 \\
\hline & 0.16 & 1.4 & $3.27 \mathrm{E}-05$ & \\
\hline & 0.34 & 4.8 & $1.81 \mathrm{E}-04$ & \\
\hline & 0.82 & 14.9 & $7.23 \mathrm{E}-04$ & \\
\hline & 1.79 & 34.0 & $1.72 \mathrm{E}-03$ & \\
\hline & 2.94 & 55.1 & $2.76 \mathrm{E}-03$ & \\
\hline & 3.69 & 68.4 & $3.38 \mathrm{E}-03$ & \\
\hline & 4.53 & 82.2 & $3.98 \mathrm{E}-03$ & \\
\hline & 5.85 & 99.6 & $4.53 \mathrm{E}-03$ & \\
\hline & 6.84 & 111.6 & $4.86 \mathrm{E}-03$ & \\
\hline & 7.94 & 122.7 & $5.06 \mathrm{E}-03$ & \\
\hline & 9.41 & 134.5 & $5.13 \mathrm{E}-03$ & \\
\hline & 13.06 & 154.6 & $4.89 \mathrm{E}-03$ & \\
\hline & & & & \\
\hline & & & Max Power & \\
\hline & & & & \\
\hline
\end{tabular}

\begin{tabular}{|c|c|c|c|c|}
\hline Cell \# & Date & 8-May-08 & & \\
\hline \multirow[t]{8}{*}{4} & Length (in) & 0.834 & Area $\left(\mathrm{cm}^{2}\right)$ & 5.2353573 \\
\hline & Width (in) & 0.973 & OCV (Volts) & 0.02 \\
\hline & $\mathrm{R}$ (kOhms) & $\mathrm{V}(\mathrm{mV})$ & Power $\left(\mathrm{W} / \mathrm{m}^{2}\right)$ & $=\left(\mathrm{V}^{2} / \mathrm{R}\right) /$ area $* 1000$ \\
\hline & 5.79 & 0.5 & $8.25 \mathrm{E}-08$ & \\
\hline & 10.97 & 1.2 & 2.51E-07 & \\
\hline & 23.5 & 2.5 & $5.08 \mathrm{E}-07$ & \\
\hline & 46 & 4.7 & 9.17E-07 & \\
\hline & 103 & 7.1 & 9.35E-07 & \\
\hline & & & & \\
\hline & & & & \\
\hline & & & & \\
\hline & & & & \\
\hline & & & & \\
\hline & & & & \\
\hline & & & & \\
\hline & & & & \\
\hline & & & Max Power & 9.35E-07 \\
\hline & & & & \\
\hline
\end{tabular}




\begin{tabular}{|r|l|r|r|r|}
\hline \multicolumn{1}{|l|}{ Cell \# } & Date & 8-May-08 & & \\
\hline 5 & Length (in) & 0.774 & Area $\left(\mathrm{cm}^{2}\right)$ & 3.5753735 \\
\hline & Width (in) & 0.716 & OCV $($ Volts) & 0.24 \\
\hline & R (kOhms) & V (mV) & Power (W/m $\left.{ }^{2}\right)$ & $=\left(\mathrm{V}^{2} / \mathrm{R}\right) /$ area 1000 \\
\hline & 0.15 & 1.3 & $3.15 \mathrm{E}-05$ & \\
\hline & 0.85 & 9.5 & $2.97 \mathrm{E}-04$ & \\
\hline & 2.52 & 29.5 & $9.66 \mathrm{E}-04$ & \\
\hline & 3.2 & 44.4 & $1.72 \mathrm{E}-03$ & \\
\hline & 4.49 & 62.9 & $2.46 \mathrm{E}-03$ & \\
\hline & 6.44 & 87.9 & $3.36 \mathrm{E}-03$ & \\
\hline & 7.3 & 108.6 & $4.52 \mathrm{E}-03$ & \\
\hline & 8.3 & 130.4 & $5.73 \mathrm{E}-03$ & \\
\hline & 9.89 & 142.6 & $5.75 \mathrm{E}-03$ & \\
\hline & 11.45 & 151.6 & $5.61 \mathrm{E}-03$ & \\
\hline & & & & \\
\hline & & & & \\
\hline & & & & \\
\hline & & & & \\
\hline
\end{tabular}

\begin{tabular}{|c|c|c|c|c|}
\hline Cell \# & Date & 8-May-08 & & \\
\hline \multirow[t]{17}{*}{7} & Length (in) & 0.737 & Area $\left(\mathrm{cm}^{2}\right)$ & 3.3711739 \\
\hline & Width (in) & 0.709 & OCV (Volts) & 0.08 \\
\hline & $\mathrm{R}$ (kOhms) & $\mathrm{V}(\mathrm{mV})$ & Power $\left(\mathrm{W} / \mathrm{m}^{2}\right)$ & $=\left(\mathrm{V}^{2} / \mathrm{R}\right) /$ area $* 1000$ \\
\hline & 2.63 & 2.2 & $5.46 \mathrm{E}-06$ & \\
\hline & 5.44 & 6.3 & $2.16 \mathrm{E}-05$ & \\
\hline & 11.05 & 15.0 & $6.04 \mathrm{E}-05$ & \\
\hline & 17.95 & 25.1 & 1.04E-04 & \\
\hline & 36.6 & 43.9 & $1.56 \mathrm{E}-04$ & \\
\hline & 71.6 & 63.9 & 1.69E-04 & \\
\hline & 80 & 71.8 & 1.91E-04 & \\
\hline & 126.3 & 87.3 & 1.79E-04 & \\
\hline & & & & \\
\hline & & & & \\
\hline & & & & \\
\hline & & & & \\
\hline & & & & \\
\hline & & & Max Power & 1.91E-04 \\
\hline & & & & \\
\hline
\end{tabular}

\begin{tabular}{|c|c|c|c|c|}
\hline Cell \# & Date & 8-May-08 & & \\
\hline \multirow[t]{17}{*}{6} & Length (in) & 0.959 & Area $\left(\mathrm{cm}^{2}\right)$ & 5.277583 \\
\hline & Width (in) & 0.853 & OCV (Volts) & 0.18 \\
\hline & $\mathrm{R}$ (kOhms) & $\mathrm{V}(\mathrm{mV})$ & Power $\left(\mathrm{W} / \mathrm{m}^{2}\right)$ & $=\left(\mathrm{V}^{2} / \mathrm{R}\right) /$ area ${ }^{*} 1000$ \\
\hline & 0.32 & 2.2 & 2.87E-05 & \\
\hline & 1.25 & 9.6 & 1.40E-04 & \\
\hline & 2.58 & 19.9 & $2.91 \mathrm{E}-04$ & \\
\hline & 3.76 & 28.8 & $4.18 \mathrm{E}-04$ & \\
\hline & 5.96 & 41.8 & $5.55 \mathrm{E}-04$ & \\
\hline & 8.05 & 52.4 & $6.46 \mathrm{E}-04$ & \\
\hline & 9.84 & 60.4 & $7.02 \mathrm{E}-04$ & \\
\hline & 13.16 & 71.6 & $7.38 \mathrm{E}-04$ & \\
\hline & 15.96 & 79.7 & 7.54E-04 & \\
\hline & 21.6 & 92.1 & 7.44E-04 & \\
\hline & & & & \\
\hline & & & & \\
\hline & & & & \\
\hline & & & Max Power & 7.54E-04 \\
\hline & & & & \\
\hline
\end{tabular}

\begin{tabular}{|c|c|c|c|c|}
\hline Cell \# & Date & 7-May-08 & & \\
\hline 8 & Length (in) & 0.934 & Area $\left(\mathrm{cm}^{2}\right)$ & 4.4771652 \\
\hline & Width (in) & 0.743 & OCV (Volts) & 0.17 \\
\hline & $\mathrm{R}$ (kOhms) & $\mathrm{V}(\mathrm{mV})$ & Power $\left(\mathrm{W} / \mathrm{m}^{2}\right)$ & $=\left(\mathrm{V}^{2} / \mathrm{R}\right) /$ area*1000 \\
\hline & 0.36 & 2.2 & 3.00E-05 & \\
\hline & 2.09 & 8 & $6.84 \mathrm{E}-05$ & \\
\hline & 3.46 & 11.3 & $8.24 \mathrm{E}-05$ & \\
\hline & 5.11 & 14.1 & 8.69E-05 & \\
\hline & 6.38 & 15.2 & 8.09E-05 & \\
\hline & 11.36 & 19.1 & 7.17E-05 & \\
\hline & & & & \\
\hline & & & & \\
\hline & & & & \\
\hline & & & & \\
\hline & & & & \\
\hline & & & & \\
\hline & & & Max Power & $869 F_{-05}$ \\
\hline & & & & \\
\hline
\end{tabular}




\begin{tabular}{|c|c|c|c|c|}
\hline Cell \# & Date & 8-May-08 & & \\
\hline \multirow[t]{17}{*}{9} & Length (in) & 0.735 & Area $\left(\mathrm{cm}^{2}\right)$ & 3.3430578 \\
\hline & Width (in) & 0.705 & OCV (Volts) & 0.2 \\
\hline & $\mathrm{R}$ (kOhms) & $\mathrm{V}(\mathrm{mV})$ & Power $\left(\mathrm{W} / \mathrm{m}^{2}\right)$ & $=\left(\mathrm{V}^{2} / \mathrm{R}\right) /$ area ${ }^{*} 1000$ \\
\hline & 0.22 & 2.4 & 7.83E-05 & \\
\hline & 0.8 & 10.4 & $4.04 \mathrm{E}-04$ & \\
\hline & 3.07 & 40.8 & $1.62 \mathrm{E}-03$ & \\
\hline & 5.88 & 76.0 & $2.94 \mathrm{E}-03$ & \\
\hline & 7.72 & 97.7 & 3.70E-03 & \\
\hline & 11.07 & 126.8 & $4.34 \mathrm{E}-03$ & \\
\hline & 14.21 & 149.7 & $4.72 \mathrm{E}-03$ & \\
\hline & 24.9 & 189.9 & $4.33 \mathrm{E}-03$ & \\
\hline & & & & \\
\hline & & & & \\
\hline & & & & \\
\hline & & & & \\
\hline & & & & \\
\hline & & & Max Power & $4.72 \mathrm{E}-03$ \\
\hline
\end{tabular}

\begin{tabular}{|c|c|c|c|c|}
\hline Cell \# & Date & 8-May-08 & & \\
\hline \multirow[t]{7}{*}{11} & Length (in) & 0.76 & Area $\left(\mathrm{cm}^{2}\right)$ & 4.1137982 \\
\hline & Width (in) & 0.839 & OCV (Volts) & 0.06 \\
\hline & $\mathrm{R}$ (kOhms) & $\mathrm{V}(\mathrm{mV})$ & Power $\left(\mathrm{W} / \mathrm{m}^{2}\right)$ & $=\left(\mathrm{V}^{2} / \mathrm{R}\right) /$ area $* 1000$ \\
\hline & 0.64 & 1.0 & 3.80E-06 & \\
\hline & 2.36 & 2.2 & 4.99E-06 & \\
\hline & 6.68 & 4.4 & 7.05E-06 & \\
\hline & 17.52 & 5.6 & 4.35E-06 & \\
\hline & & & & \\
\hline & & & & \\
\hline & & & & \\
\hline & & & & \\
\hline & & & & \\
\hline & & & & \\
\hline & & & & \\
\hline & & & & \\
\hline & & & & \\
\hline & & & Max Power & 7.05E-06 \\
\hline & & & & \\
\hline
\end{tabular}

\begin{tabular}{|c|c|c|c|c|}
\hline Cell \# & Date & 8-Мау-08 & & \\
\hline \multirow[t]{7}{*}{10} & Length (in) & 1.019 & Area $\left(\mathrm{cm}^{2}\right)$ & 5.4697181 \\
\hline & Width (in) & 0.832 & OCV (Volts) & 0.01 \\
\hline & $\mathrm{R}$ (kOhms) & $\mathrm{V}(\mathrm{mV})$ & Power $\left(\mathrm{W} / \mathrm{m}^{2}\right)$ & $=\left(\mathrm{V}^{2} / \mathrm{R}\right) /$ area $* 1000$ \\
\hline & 0.63 & 0.4 & 4.64E-07 & \\
\hline & 7.94 & 3.6 & $2.98 \mathrm{E}-06$ & \\
\hline & 15.66 & 6.2 & 4.49E-06 & \\
\hline & 37.5 & 8.5 & $3.52 \mathrm{E}-06$ & \\
\hline & & & & \\
\hline & & & & \\
\hline & & & & \\
\hline & & & & \\
\hline & & & & \\
\hline & & & & \\
\hline & & & & \\
\hline & & & & \\
\hline & & & & \\
\hline & & & Max Power & 4.49E-06 \\
\hline & & & & \\
\hline
\end{tabular}

\begin{tabular}{|c|c|c|c|c|}
\hline Cell \# & Date & 7-May-08 & & \\
\hline \multirow[t]{7}{*}{12} & Length (in) & 0.707 & Area $\left(\mathrm{cm}^{2}\right)$ & 4.8486419 \\
\hline & Width (in) & 1.063 & OCV (Volts) & 0.12 \\
\hline & $\mathrm{R}$ (kOhms) & $\mathrm{V}(\mathrm{mV})$ & Power $\left(\mathrm{W} / \mathrm{m}^{2}\right)$ & $=\left(\mathrm{V}^{2} / \mathrm{R}\right) /$ area ${ }^{*} 1000$ \\
\hline & 0.29 & 1.1 & 8.61E-06 & \\
\hline & 0.73 & 2.9 & $2.38 \mathrm{E}-05$ & \\
\hline & 3.28 & 10.8 & 7.33E-05 & \\
\hline & 5.28 & 14.2 & $7.88 \mathrm{E}-05$ & \\
\hline & & & & \\
\hline & & & & \\
\hline & & & & \\
\hline & & & & \\
\hline & & & & \\
\hline & & & & \\
\hline & & & & \\
\hline & & & & \\
\hline & & & & \\
\hline & & & Max Power & 7.88E-05 \\
\hline & & & & \\
\hline
\end{tabular}




\begin{tabular}{|c|c|c|c|c|}
\hline Cell \# & Date & 6-May-08 & & \\
\hline \multirow[t]{17}{*}{13} & Length (in) & 0.89 & Area $\left(\mathrm{cm}^{2}\right)$ & 3.6461217 \\
\hline & Width (in) & 0.635 & OCV (Volts) & 0.27 \\
\hline & $\mathrm{R}(\mathrm{kOhms})$ & $\mathrm{V}(\mathrm{mV})$ & Power $\left(\mathrm{W} / \mathrm{m}^{2}\right)$ & $=\left(\mathrm{V}^{2} / \mathrm{R}\right) /$ area $* 1000$ \\
\hline & 0.416 & 5 & 1.65E-04 & \\
\hline & 2.3 & 26 & $8.06 \mathrm{E}-04$ & \\
\hline & 4.32 & 41.3 & $1.08 \mathrm{E}-03$ & \\
\hline & 5.38 & 50.8 & $1.32 \mathrm{E}-03$ & \\
\hline & 6.46 & 58.1 & $1.43 \mathrm{E}-03$ & \\
\hline & 9.66 & 75.3 & $1.61 \mathrm{E}-03$ & \\
\hline & 13.17 & 88.5 & $1.63 \mathrm{E}-03$ & \\
\hline & 16.76 & 99.5 & $1.62 \mathrm{E}-03$ & \\
\hline & & & & \\
\hline & & & & \\
\hline & & & & \\
\hline & & & & \\
\hline & & & & \\
\hline & & & Max Power & 1.63E-03 \\
\hline & & & & \\
\hline
\end{tabular}

\begin{tabular}{|c|c|c|c|c|}
\hline Cell \# & Date & 7-May-08 & & \\
\hline \multirow[t]{9}{*}{14} & Length (in) & 0.887 & Area $\left(\mathrm{cm}^{2}\right)$ & 5.579505 \\
\hline & Width (in) & 0.975 & OCV (Volts) & 0.1 \\
\hline & $\mathrm{R}$ (kOhms) & $\mathrm{V}(\mathrm{mV})$ & Power $\left(\mathrm{W} / \mathrm{m}^{2}\right)$ & $=\left(\mathrm{V}^{2} / \mathrm{R}\right) /$ area $* 1000$ \\
\hline & 0.34 & 1.9 & 1.90E-05 & \\
\hline & 1.93 & 9.2 & 7.86E-05 & \\
\hline & 4.9 & 17.6 & $1.13 \mathrm{E}-04$ & \\
\hline & 7.01 & 21.9 & $1.23 \mathrm{E}-04$ & \\
\hline & 9.37 & 26.1 & $1.30 \mathrm{E}-04$ & \\
\hline & 13.43 & 28.2 & $1.06 \mathrm{E}-04$ & \\
\hline & & & & \\
\hline & & & & \\
\hline & & & & \\
\hline & & & & \\
\hline & & & & \\
\hline & & & & \\
\hline & & & & \\
\hline & & & Max Power & 1.30E-04 \\
\hline & & & & \\
\hline
\end{tabular}

\begin{tabular}{|c|c|c|c|c|}
\hline Cell \# & Date & 8-May-08 & & \\
\hline \multirow[t]{17}{*}{15} & Length (in) & 1.08 & Area $\left(\mathrm{cm}^{2}\right)$ & 6.0061815 \\
\hline & Width (in) & 0.862 & OCV (Volts) & 0.29 \\
\hline & $\mathrm{R}$ (kOhms) & $\mathrm{V}(\mathrm{mV})$ & Power $\left(\mathrm{W} / \mathrm{m}^{2}\right)$ & $=\left(\mathrm{V}^{2} / \mathrm{R}\right) /$ area $* 1000$ \\
\hline & 0.18 & 5.4 & 2.70E-04 & \\
\hline & 4.93 & 108.6 & $3.98 \mathrm{E}-03$ & \\
\hline & 5.57 & 120.6 & $4.35 \mathrm{E}-03$ & \\
\hline & 6.61 & 137.6 & $4.77 \mathrm{E}-03$ & \\
\hline & 7.68 & 152.6 & $5.05 \mathrm{E}-03$ & \\
\hline & 8.95 & 167.5 & $5.22 \mathrm{E}-03$ & \\
\hline & 10.78 & 186.8 & 5.39E-03 & \\
\hline & 12.87 & 201.0 & $5.23 E-03$ & \\
\hline & & & & \\
\hline & & & & \\
\hline & & & & \\
\hline & & & & \\
\hline & & & & \\
\hline & & & Max Power & 5.39E-03 \\
\hline & & & & \\
\hline
\end{tabular}

\begin{tabular}{|c|c|c|c|c|}
\hline Cell \# & Date & 7-May-08 & & \\
\hline \multirow[t]{9}{*}{16} & Length (in) & 0.708 & Area $\left(\mathrm{cm}^{2}\right)$ & 4.1246627 \\
\hline & Width (in) & 0.903 & OCV (Volts) & 0.11 \\
\hline & R (kOhms) & $\mathrm{V}(\mathrm{mV})$ & Power $\left(\mathrm{W} / \mathrm{m}^{2}\right)$ & $=\left(V^{2} / R\right) / a r e a * 1000$ \\
\hline & 0.3 & 1.9 & 2.92E-05 & \\
\hline & 1.6 & 8.9 & $1.20 \mathrm{E}-04$ & \\
\hline & 4.2 & 16.1 & $1.50 \mathrm{E}-04$ & \\
\hline & 6.39 & 20.6 & $1.61 \mathrm{E}-04$ & \\
\hline & 9.02 & 24.7 & $1.64 \mathrm{E}-04$ & \\
\hline & 12.33 & 28.3 & 1.57E-04 & \\
\hline & & & & \\
\hline & & & & \\
\hline & & & & \\
\hline & & & & \\
\hline & & & & \\
\hline & & & & \\
\hline & & & & \\
\hline & & & Max Power & 1.64E-04 \\
\hline & & & & \\
\hline
\end{tabular}




\begin{tabular}{|c|c|c|c|c|}
\hline Cell \# & Date & 7-Mar-08 & & \\
\hline \multirow[t]{8}{*}{17} & Length (in) & 0.842 & Area $\left(\mathrm{cm}^{2}\right)$ & 2.9062523 \\
\hline & Width (in) & 0.535 & OCV (Volts) & 0.11 \\
\hline & $\mathrm{R}$ (kOhms) & $\mathrm{V}(\mathrm{mV})$ & Power $\left(\mathrm{W} / \mathrm{m}^{2}\right)$ & $=\left(\mathrm{V}^{2} / \mathrm{R}\right) /$ area*1000 \\
\hline & 1.56 & 12.78 & 3.60E-04 & \\
\hline & 15.5 & 64.1 & $9.12 \mathrm{E}-04$ & \\
\hline & 34.8 & 84.5 & 7.06E-04 & \\
\hline & 73.6 & 97.9 & $4.48 \mathrm{E}-04$ & \\
\hline & 94.3 & 103.3 & 3.89E-04 & \\
\hline & & & & \\
\hline & & & & \\
\hline & & & & \\
\hline & & & & \\
\hline & & & & \\
\hline & & & & \\
\hline & & & & \\
\hline & & & & \\
\hline & & & Max Power & $9.12 \mathrm{E}-04$ \\
\hline & & & & \\
\hline
\end{tabular}

\begin{tabular}{|c|c|c|c|c|}
\hline Cell \# & Date & 7-Mar-08 & & \\
\hline \multirow[t]{7}{*}{19} & Length (in) & 0.625 & Area $\left(\mathrm{cm}^{2}\right)$ & 3.3467675 \\
\hline & Width (in) & 0.83 & OCV (Volts) & 0.23 \\
\hline & $\mathrm{R}$ (kOhms) & $\mathrm{V}(\mathrm{mV})$ & Power $\left(\mathrm{W} / \mathrm{m}^{2}\right)$ & $=\left(\mathrm{V}^{2} / \mathrm{R}\right) /$ area ${ }^{*} 1000$ \\
\hline & 0.88 & 4.8 & 7.82E-05 & \\
\hline & 12.9 & 43.2 & $4.32 \mathrm{E}-04$ & \\
\hline & 44.9 & 83 & $4.58 \mathrm{E}-04$ & \\
\hline & 61.8 & 93.4 & $4.22 \mathrm{E}-04$ & \\
\hline & & & & \\
\hline & & & & \\
\hline & & & & \\
\hline & & & & \\
\hline & & & & \\
\hline & & & & \\
\hline & & & & \\
\hline & & & & \\
\hline & & & & \\
\hline & & & Max Power & $4.58 \mathrm{E}-04$ \\
\hline & & & & \\
\hline & & & & \\
\hline
\end{tabular}

\begin{tabular}{|c|c|c|c|c|}
\hline Cell \# & Date & 8-Apr-08 & & \\
\hline \multirow[t]{7}{*}{18} & Length (in) & 0.775 & Area $\left(\mathrm{cm}^{2}\right)$ & 4.8599903 \\
\hline & Width (in) & 0.972 & OCV (Volts) & 0.21 \\
\hline & $\mathrm{R}$ (kOhms) & $\mathrm{V}(\mathrm{mV})$ & Power $\left(\mathrm{W} / \mathrm{m}^{2}\right)$ & $=\left(\mathrm{V}^{2} / \mathrm{R}\right) /$ area*1000 \\
\hline & 0.56 & 0.17 & 1.06E-07 & \\
\hline & 3.61 & 1.08 & $6.65 \mathrm{E}-07$ & \\
\hline & 38.7 & 2.90 & 4.47E-07 & \\
\hline & 115.47 & 3.95 & $2.78 \mathrm{E}-07$ & \\
\hline & & & & \\
\hline & & & & \\
\hline & & & & \\
\hline & & & & \\
\hline & & & & \\
\hline & & & & \\
\hline & & & & \\
\hline & & & & \\
\hline & & & & \\
\hline & & & Max Power & 6.65E-07 \\
\hline & & & & \\
\hline
\end{tabular}

\begin{tabular}{|c|c|c|c|c|}
\hline Cell \# & Date & 8-Apr-08 & & \\
\hline \multirow[t]{17}{*}{20} & Length (in) & 0.754 & Area $\left(\mathrm{cm}^{2}\right)$ & 4.6699261 \\
\hline & Width (in) & 0.96 & OCV (Volts) & 0.05 \\
\hline & $\mathrm{R}$ (kOhms) & $\mathrm{V}(\mathrm{mV})$ & Power $\left(\mathrm{W} / \mathrm{m}^{2}\right)$ & $=\left(\mathrm{V}^{2} / \mathrm{R}\right) /$ area $* 1000$ \\
\hline & 0.402 & 1.58 & 1.33E-05 & \\
\hline & 0.828 & 3.65 & $3.45 \mathrm{E}-05$ & \\
\hline & 3.116 & 13.50 & $1.25 \mathrm{E}-04$ & \\
\hline & 4.38 & 18.60 & $1.69 \mathrm{E}-04$ & \\
\hline & 13.99 & 38.93 & $2.32 \mathrm{E}-04$ & \\
\hline & 27.89 & 58.75 & $2.65 \mathrm{E}-04$ & \\
\hline & 34.01 & 71.49 & $3.22 \mathrm{E}-04$ & \\
\hline & & & & \\
\hline & & & & \\
\hline & & & & \\
\hline & & & & \\
\hline & & & & \\
\hline & & & & \\
\hline & & & Max Power & $3.22 \mathrm{E}-04$ \\
\hline
\end{tabular}




\begin{tabular}{|c|c|c|c|c|}
\hline Cell \# & Date & 7-Mar-08 & & \\
\hline \multirow[t]{8}{*}{21} & Length (in) & 0.772 & Area $\left(\mathrm{cm}^{2}\right)$ & 3.0879938 \\
\hline & Width (in) & 0.62 & OCV (Volts) & 0.22 \\
\hline & $\mathrm{R}$ (kOhms) & $\mathrm{V}(\mathrm{mV})$ & Power $\left(\mathrm{W} / \mathrm{m}^{2}\right)$ & $=\left(\mathrm{V}^{2} / \mathrm{R}\right) /$ area*1000 \\
\hline & 1.37 & 11.25 & 2.99E-04 & \\
\hline & 3.08 & 36 & 1.36E-03 & \\
\hline & 9.35 & 92.5 & $2.96 \mathrm{E}-03$ & \\
\hline & 10.9 & 112.7 & $3.77 \mathrm{E}-03$ & \\
\hline & 23.6 & 169.3 & $3.93 \mathrm{E}-03$ & \\
\hline & & & & \\
\hline & & & & \\
\hline & & & & \\
\hline & & & & \\
\hline & & & & \\
\hline & & & & \\
\hline & & & & \\
\hline & & & & \\
\hline & & & Max Power & 3.93E-03 \\
\hline & & & & \\
\hline
\end{tabular}

\begin{tabular}{|c|c|c|c|c|}
\hline Cell \# & Date & 9-May-08 & & \\
\hline \multirow[t]{10}{*}{23} & Length (in) & 0.806 & Area $\left(\mathrm{cm}^{2}\right)$ & 3.5619929 \\
\hline & Width (in) & 0.685 & OCV (Volts) & 0.15 \\
\hline & $\mathrm{R}$ (kOhms) & $\mathrm{V}(\mathrm{mV})$ & Power $\left(\mathrm{W} / \mathrm{m}^{2}\right)$ & $=\left(\mathrm{V}^{2} / \mathrm{R}\right) /$ area $* 1000$ \\
\hline & 0.31 & 3.4 & 1.05E-04 & \\
\hline & 2.2 & 22.7 & $6.58 \mathrm{E}-04$ & \\
\hline & 4.81 & 45.3 & $1.20 \mathrm{E}-03$ & \\
\hline & 9.79 & 75.3 & 1.63E-03 & \\
\hline & 14.52 & 94.6 & 1.73E-03 & \\
\hline & 18.2 & 109.4 & 1.85E-03 & \\
\hline & 23.3 & 116.7 & 1.64E-03 & \\
\hline & & & & \\
\hline & & & & \\
\hline & & & & \\
\hline & & & & \\
\hline & & & & \\
\hline & & & & \\
\hline & & & Max Power & 1.85E-03 \\
\hline & & & & \\
\hline
\end{tabular}

\begin{tabular}{|c|c|c|c|c|}
\hline Cell \# & Date & 8-Apr-08 & & \\
\hline \multirow[t]{10}{*}{22} & Length (in) & 0.819 & Area $\left(\mathrm{cm}^{2}\right)$ & 5.0196674 \\
\hline & Width (in) & 0.95 & OCV (Volts) & 0.27 \\
\hline & $\mathrm{R}$ (kOhms) & $\mathrm{V}(\mathrm{mV})$ & Power $\left(\mathrm{W} / \mathrm{m}^{2}\right)$ & $=\left(\mathrm{V}^{2} / \mathrm{R}\right) /$ area $* 1000$ \\
\hline & 0.851 & 4.83 & 5.46E-05 & \\
\hline & 3.406 & 21.75 & $2.77 \mathrm{E}-04$ & \\
\hline & 8.673 & 104.91 & $2.53 \mathrm{E}-03$ & \\
\hline & 13.65 & 134.13 & $2.63 \mathrm{E}-03$ & \\
\hline & 17.132 & 166.23 & $3.21 \mathrm{E}-03$ & \\
\hline & 21.94 & 179.61 & $2.93 \mathrm{E}-03$ & \\
\hline & 26.431 & 198.55 & $2.97 \mathrm{E}-03$ & \\
\hline & & & & \\
\hline & & & & \\
\hline & & & & \\
\hline & & & & \\
\hline & & & & \\
\hline & & & Max Power & $3.21 \mathrm{E}-03$ \\
\hline & & & & \\
\hline
\end{tabular}

\begin{tabular}{|c|c|c|c|c|}
\hline Cell \# & Date & 8-Apr-08 & & \\
\hline \multirow[t]{9}{*}{24} & Length (in) & 0.798 & Area $\left(\mathrm{cm}^{2}\right)$ & 5.0711511 \\
\hline & Width (in) & 0.985 & OCV (Volts) & 0.15 \\
\hline & $\mathrm{R}$ (kOhms) & $\mathrm{V}(\mathrm{mV})$ & Power $\left(\mathrm{W} / \mathrm{m}^{2}\right)$ & $=\left(\mathrm{V}^{2} / \mathrm{R}\right) /$ area $* 1000$ \\
\hline & 1.04 & 11.75 & $2.62 \mathrm{E}-04$ & \\
\hline & 1.315 & 15.81 & 3.75E-04 & \\
\hline & 3.804 & 39.83 & 8.22E-04 & \\
\hline & 8.59 & 73.75 & 1.25E-03 & \\
\hline & 12.63 & 86.1 & $1.16 \mathrm{E}-03$ & \\
\hline & 20.79 & 103.68 & $1.02 \mathrm{E}-03$ & \\
\hline & & & & \\
\hline & & & & \\
\hline & & & & \\
\hline & & & & \\
\hline & & & & \\
\hline & & & & \\
\hline & & & & \\
\hline & & & Max Power & 1.25E-03 \\
\hline & & & & \\
\hline
\end{tabular}




\begin{tabular}{|r|l|r|r|r|}
\hline \multicolumn{1}{|l|}{ Cell \# } & Date & 7-Mar-08 & & \\
\hline 25 & Length (in) & 0.86 & Area $\left(\mathrm{cm}^{2}\right)$ & 3.8394762 \\
\hline & Width (in) & 0.692 & OCV (Volts) & 0.27 \\
\hline & R (kOhms) & V (mV) & Power (W/m $\left.{ }^{2}\right)$ & $=\left(\mathrm{V}^{2} / \mathrm{R}\right) /$ area*1000 \\
\hline & 2.02 & 11.95 & $1.84 \mathrm{E}-04$ & \\
\hline & 20.11 & 78.4 & $7.96 \mathrm{E}-04$ & \\
\hline & 30.04 & 100.2 & $8.70 \mathrm{E}-04$ & \\
\hline & 41.66 & 113.5 & $8.05 \mathrm{E}-04$ & \\
\hline & 53.5 & 130.4 & $8.28 \mathrm{E}-04$ & \\
\hline & & & & \\
\hline & & & & \\
\hline & & & & \\
\hline & & & & \\
\hline & & & & \\
\hline & & & & \\
\hline & & & & \\
\hline & & & & \\
\hline & & & & \\
\hline
\end{tabular}

\begin{tabular}{|c|c|c|c|c|}
\hline Cell \# & Date & 7-Mar-08 & & \\
\hline \multirow[t]{9}{*}{27} & Length (in) & 0.652 & Area $\left(\mathrm{cm}^{2}\right)$ & 3.4661092 \\
\hline & Width (in) & 0.824 & OCV (Volts) & 0.32 \\
\hline & $\mathrm{R}$ (kOhms) & $\mathrm{V}(\mathrm{mV})$ & Power $\left(\mathrm{W} / \mathrm{m}^{2}\right)$ & $=\left(\mathrm{V}^{2} / \mathrm{R}\right) /$ area*1000 \\
\hline & 0.467 & 8.3 & $4.26 \mathrm{E}-04$ & \\
\hline & 1.05 & 18.3 & $9.20 \mathrm{E}-04$ & \\
\hline & 3.3 & 53.3 & $2.48 \mathrm{E}-03$ & \\
\hline & 9.75 & 118.6 & $4.16 \mathrm{E}-03$ & \\
\hline & 14.23 & 147.5 & $4.41 \mathrm{E}-03$ & \\
\hline & 22.23 & 175.2 & 3.98E-03 & \\
\hline & & & & \\
\hline & & & & \\
\hline & & & & \\
\hline & & & & \\
\hline & & & & \\
\hline & & & & \\
\hline & & & & \\
\hline & & & Max Power & 4.41E-03 \\
\hline & & & & \\
\hline
\end{tabular}

\begin{tabular}{|c|c|c|c|c|}
\hline Cell \# & Date & 8-Apr-08 & & \\
\hline \multirow[t]{10}{*}{26} & Length (in) & 0.752 & Area $\left(\mathrm{cm}^{2}\right)$ & 4.7739775 \\
\hline & Width (in) & 0.984 & OCV (Volts) & 0.03 \\
\hline & $\mathrm{R}$ (kOhms) & $\mathrm{V}(\mathrm{mV})$ & Power $\left(\mathrm{W} / \mathrm{m}^{2}\right)$ & $=\left(\mathrm{V}^{2} / \mathrm{R}\right) /$ area $* 1000$ \\
\hline & 0.706 & 1.18 & 4.13E-06 & \\
\hline & 1.156 & 2.46 & 1.10E-05 & \\
\hline & 5.852 & 8.34 & $2.49 \mathrm{E}-05$ & \\
\hline & 7.566 & 12.49 & $4.32 \mathrm{E}-05$ & \\
\hline & 18.76 & 20.48 & $4.68 \mathrm{E}-05$ & \\
\hline & 22.73 & 22.02 & $4.47 \mathrm{E}-05$ & \\
\hline & 36.132 & 24.50 & $3.48 \mathrm{E}-05$ & \\
\hline & & & & \\
\hline & & & & \\
\hline & & & & \\
\hline & & & & \\
\hline & & & & \\
\hline & & & & \\
\hline & & & Max Power & 4.68E-05 \\
\hline
\end{tabular}

\begin{tabular}{|c|c|c|c|c|}
\hline Cell \# & Date & 8-Apr-08 & & \\
\hline \multirow[t]{6}{*}{28} & Length (in) & 0.792 & Area $\left(\mathrm{cm}^{2}\right)$ & 5.4826729 \\
\hline & Width (in) & 1.073 & OCV (Volts) & 0.06 \\
\hline & $\mathrm{R}(\mathrm{kOhms})$ & $\mathrm{V}(\mathrm{mV})$ & Power $\left(\mathrm{W} / \mathrm{m}^{2}\right)$ & $=\left(V^{2} / R\right) /$ area $* 1000$ \\
\hline & 0.951 & 1.63 & 5.10E-06 & \\
\hline & 3.265 & 4.90 & 1.34E-05 & \\
\hline & 18.208 & 12.03 & $1.45 \mathrm{E}-05$ & \\
\hline & & & & \\
\hline & & & & \\
\hline & & & & \\
\hline & & & & \\
\hline & & & & \\
\hline & & & & \\
\hline & & & & \\
\hline & & & & \\
\hline & & & & \\
\hline & & & & \\
\hline & & & Max Power & 1.45E-05 \\
\hline & & & & \\
\hline
\end{tabular}




\begin{tabular}{|c|c|c|c|c|}
\hline Cell \# & Date & 7-Mar-08 & & \\
\hline \multirow[t]{8}{*}{29} & Length (in) & 0.682 & Area $\left(\mathrm{cm}^{2}\right)$ & 3.7531925 \\
\hline & Width (in) & 0.853 & OCV (Volts) & 0.28 \\
\hline & $\mathrm{R}$ (kOhms) & $\mathrm{V}(\mathrm{mV})$ & Power $\left(\mathrm{W} / \mathrm{m}^{2}\right)$ & $=\left(\mathrm{V}^{2} / \mathrm{R}\right) /$ area*1000 \\
\hline & 0.95 & 18.95 & $1.01 \mathrm{E}-03$ & \\
\hline & 4.03 & 76.5 & $3.87 \mathrm{E}-03$ & \\
\hline & 13.4 & 150.1 & $4.48 \mathrm{E}-03$ & \\
\hline & 17.1 & 165.5 & $4.27 \mathrm{E}-03$ & \\
\hline & 29.64 & 185.8 & $3.10 \mathrm{E}-03$ & \\
\hline & & & & \\
\hline & & & & \\
\hline & & & & \\
\hline & & & & \\
\hline & & & & \\
\hline & & & & \\
\hline & & & & \\
\hline & & & Max Power & 4.48E-03 \\
\hline & & & & \\
\hline
\end{tabular}

\begin{tabular}{|c|c|c|c|c|}
\hline Cell \# & Date & 7-Mar-08 & & \\
\hline \multirow[t]{7}{*}{31} & Length (in) & 0.558 & Area $\left(\mathrm{cm}^{2}\right)$ & 2.8475943 \\
\hline & Width (in) & 0.791 & OCV (Volts) & 0.14 \\
\hline & $\mathrm{R}$ (kOhms) & $\mathrm{V}(\mathrm{mV})$ & Power $\left(\mathrm{W} / \mathrm{m}^{2}\right)$ & $=\left(\mathrm{V}^{2} / \mathrm{R}\right) /$ area $* 1000$ \\
\hline & 2.51 & 15.3 & $3.28 \mathrm{E}-04$ & \\
\hline & 18.2 & 38.25 & $2.82 \mathrm{E}-04$ & \\
\hline & 25.1 & 63.5 & $5.64 \mathrm{E}-04$ & \\
\hline & 70.45 & 75.9 & 2.87E-04 & \\
\hline & & & & \\
\hline & & & & \\
\hline & & & & \\
\hline & & & & \\
\hline & & & & \\
\hline & & & & \\
\hline & & & & \\
\hline & & & Max Power & 5.64E-04 \\
\hline & & & & \\
\hline
\end{tabular}

\begin{tabular}{|c|c|c|c|c|}
\hline Cell \# & Date & 8-Apr-08 & & \\
\hline \multirow[t]{17}{*}{30} & Length (in) & 0.975 & Area $\left(\mathrm{cm}^{2}\right)$ & 5.2209573 \\
\hline & Width (in) & 0.83 & OCV (Volts) & 0.1 \\
\hline & $\mathrm{R}$ (kOhms) & $\mathrm{V}(\mathrm{mV})$ & Power $\left(\mathrm{W} / \mathrm{m}^{2}\right)$ & $=\left(\mathrm{V}^{2} / \mathrm{R}\right) /$ area $* 1000$ \\
\hline & 0.288 & 2.8 & 5.21E-05 & \\
\hline & 0.407 & 4.43 & 9.24E-05 & \\
\hline & 0.567 & 6.46 & $1.41 \mathrm{E}-04$ & \\
\hline & 1.041 & 11.69 & $2.51 \mathrm{E}-04$ & \\
\hline & 3.363 & 29.1 & $4.82 \mathrm{E}-04$ & \\
\hline & 5.081 & 37.97 & $5.43 \mathrm{E}-04$ & \\
\hline & 12.22 & 56.92 & $5.08 \mathrm{E}-04$ & \\
\hline & 16.96 & 64.9 & $4.76 \mathrm{E}-04$ & \\
\hline & & & & \\
\hline & & & & \\
\hline & & & & \\
\hline & & & & \\
\hline & & & Max Power & 5.43E-04 \\
\hline & & & & \\
\hline
\end{tabular}

\begin{tabular}{|c|c|c|c|c|}
\hline Cell \# & Date & 8-Apr-08 & & \\
\hline 32 & Length (in) & 0.862 & Area $\left(\mathrm{cm}^{2}\right)$ & 5.2053573 \\
\hline & Width (in) & 0.936 & OCV (Volts) & 0.39 \\
\hline & $\mathrm{R}$ (kOhms) & $\mathrm{V}(\mathrm{mV})$ & Power $\left(\mathrm{W} / \mathrm{m}^{2}\right)$ & $=\left(\mathrm{V}^{2} / \mathrm{R}\right) /$ area $* 1000$ \\
\hline & 0.362 & 14.43 & 1.11E-03 & \\
\hline & 1.354 & 50.50 & $3.62 \mathrm{E}-03$ & \\
\hline & 3.81 & 114.56 & $6.62 \mathrm{E}-03$ & \\
\hline & 7.325 & 168.22 & $7.42 \mathrm{E}-03$ & \\
\hline & 11.801 & 153.26 & $3.82 \mathrm{E}-03$ & \\
\hline & 20.85 & 155.72 & $2.23 \mathrm{E}-03$ & \\
\hline & & & & \\
\hline & & & & \\
\hline & & & & \\
\hline & & & & \\
\hline & & & & \\
\hline & & & & \\
\hline & & & Max Power & $742 \mathrm{E}-03$ \\
\hline
\end{tabular}




\section{References}

${ }^{1}$ Grätzel, Micheal. "Photoelectrochemical cells." Nature 41415 Nov 2001 338-344. 4 Mar 2008

$<$ http://www.nature.com/nature/journal/v414/n6861/full/414338a0.html $>$.

${ }^{2}$ Spanggaard, Holger. "A brief history of the development of organic and polymeric photovoltaics ." $\underline{\text { Solar }}$ Energy Materials and Solar Cells 83. IS 2-315 June 2004 125-146. 5 Mar 2008

$<$ http://www.sciencedirect.com/science/article/B6V51-4C70CCC-

3/2/b04861cbbea5c42ed88d2bb63a419806>.

${ }^{3}$ Purvis, Gail. "Two-year time slot for solar." III-Vs Review 19. 4 May 2006 25-28. 5 Mar 2008 $<$ http://www.sciencedirect.com/science/article/B6VM5-4K77FTN-

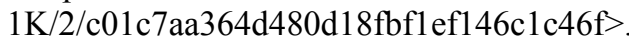

${ }^{4}$ Grätzel, Micheal. "Demonstrating Electron Transfer and Nanotechnology: A Natural Dye Sensitized Nanocrystalline Energy Converter." Journal of Chemical Education 75. No 6 (1998): 752-756.

${ }^{5}$ Solaronix SA, "Dyes - Wide Band-Gap Sensitizers." solaronix/products/dyes/. 2008. Solaronix. 4 Mar $2008<\mathrm{http}: / /$ www.solaronix.ch/products/dyes/>.

${ }^{6}$ H. Tang, J. Shinar. "Enhanced Electron Injection in Organic Electroluminescence Devices Using AL/LiF Electrode." J. Appl. Phys. Lett. 71 (1997): 2560.

${ }^{7}$ Brabec CJ, Shaheen SE. " Effect of LiF/metal electrodes on the performance of plastic solar cells ." APPLIED PHYSICS LETTERS Volume: 80 Issue: 7 (2002): 1288-1290.

${ }^{8}$ Photovoltaic Effect and Photoconductivity in Laminated Organic Systems D. Kearns and M.J. Calvin. Chem. Phys. 29 (1958), p. 950.

${ }^{9}$ Transient Photovoltaic Effects in Metal-Chlorophyll-Metal Sandwich Cells. C.W. Tang and A.C. Albrecht. J. Chem. Phys. 63 (1975), p. 953.

${ }^{10}$ Two-layer organic photovoltaic cell. C.W. Tang, US Patent 4,164,431, August 14, 1979; C.W. Tang. Appl. Phys. Lett. 48 (1986), p. 183.

${ }^{11}$ Grätzel, Michael . "The artificial leaf, molecular photovoltaics achieve efficient generation of electricity from sunlight ." Coordination Chemistry Reviews Volume 1116 December 1991 Pages 167-174. 16 May $08<$ http://www.sciencedirect.com/science?_ob=ArticleURL\&_udi=B6TFW-42SY134-

2C\&_user $=768492 \&$ coverDate $=12 \% 2 \mathrm{~F} 06 \% 2 \mathrm{~F} 1991 \&$ alid $=740616400 \&$ rdoc $=94 \&$ fmt $=$ high \&_orig $=\mathrm{se}$ 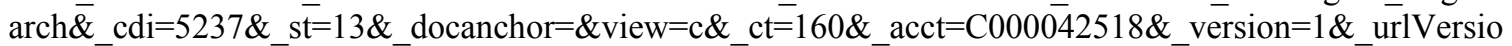 $\mathrm{n}=0 \&$ userid $=768492 \& \mathrm{md} \overline{5}=6 \mathrm{~b} 2 \mathrm{db} 15 \mathrm{eddfaff} 945 \mathrm{e} 1 \overline{7} 4 \mathrm{~d} 81 \mathrm{e} 18 \overline{9} 1 \mathrm{c} 19>$.

${ }^{12}$ Olea, Alfredo, Georgina Ponce, and P. J. Sebastian. "Electron transfer via organic dyes for solar conversion ." Solar Energy Materials and Solar Cells Volume 59, Issues 1-2, September 1999, Pages 13714319 May $2008<\mathrm{http}: / /$ www.sciencedirect.com/science?_ob=ArticleURL\&_udi=B6V51-3X7MCVFF\&_user $=768492 \&$ _coverDate $=09 \% 2 \mathrm{~F} 30 \% 2 \mathrm{~F} 1999 \&$ \& alid $=741807035 \&$ rdoc $=177 \&$ fmt $=$ high \&_orig $=\mathrm{se}$ $\operatorname{arch} \&$ cdi $=5773 \&$ st $=13 \&$ docanchor $=\&$ view $=\mathrm{c} \&$ ct $=198 \&$ acct $=$ C000042518\&_version $=1 \&$ urlVersio $\mathrm{n}=0 \&$ _userid $=768492 \& \mathrm{md} 5=8 \mathrm{e} 2 \mathrm{cdc} 113 \mathrm{c} 01 \mathrm{c} 361673 \mathrm{~d} 24 \mathrm{~d} 23 \mathrm{a} 95 \mathrm{fbd} 6>$.

${ }^{13}$ Department of Chemistry, "Manual - How to make your own Grätzel Solar Cells." Loughborough University, Leicestershire, LE11 3TU, UK. 19 May 2008

$<$ http://www.lboro.ac.uk/departments/cm/business/Gratzel.html $>$. 


\footnotetext{
${ }^{14}$ Nazeeruddin,, M. K., Grätzel, M., et al. "Conversion of Light to Electricity by cis-XzBis( 2,2'-bipyridyl4,4'-dicarboxylate)ruthenium( 11) Charge-Transfer Sensitizers (X=C1-, Br-, I-, CN-, and SCN-) on Nanocrystalline Ti02 Electrodes." J. Am. Chem. SOC 115(1992): 6382-6390.

${ }^{15}$ Kohle, Oliver . "Ruthenium(II) Charge-Transfer Sensitizers Containing 4,4'-Dicarboxy-2,2'-bipyridine. Synthesis, Properties, and Bonding Mode of Coordinated Thio- and Selenocyanates ." Inorg. Chem., 35 (16), $4779-4787,1996,16$ May $08<$ http://pubs.acs.org/cgibin/article.cgi/inocaj/1996/35/i16/html/ic9515665.html>.

${ }^{16}$ T. Renouard, et, al. "Novel Ruthenium Sensitizers Containing Functionalized Hybrid Tetradentate Ligands: Synthesis, Characterization, and INDO/S Analysis ." Inorg. Chem., 41 (2), 367 -378, 2002. 16 May $08<$ http://pubs.acs.org/cgi-bin/article.cgi/inocaj/2002/41/i02/html/ic010512u.html>.
}

${ }^{17}$ Ying-Chan Hsu, Hegen Zhengb, Jiann T'suen Linc and Kuo-Chuan Ho. "On the structural variations of $\mathrm{Ru}(\mathrm{II})$ complexes for dye-sensitized solar cells." Solar Energy Materials and Solar Cells Volume 87, Issues 1-4, May 2005, Pages 357-367 19 May 2008

$<$ http://www.sciencedirect.com/science? ob=ArticleURL\&_udi=B6V51-4DVW4F6-

$1 \&$ user $=768492 \&$ _coverDate $=05 \% 2 \mathrm{~F} 31 \% 2 \mathrm{~F} 2005 \&$ alid $=741807035 \&$ rdoc $=99 \&$ fmt $=$ high $\&$ orig $=$ sea $\mathrm{rch} \& \_\mathrm{cdi}=5773 \& \_\mathrm{st}=13 \& \_$docanchor $=\& \mathrm{view}=\mathrm{c} \& \_\mathrm{ct}=198 \& \_\mathrm{acct}=\mathrm{C} 000042518 \&$ \&ersion $=1 \&$ urlVersion $=0 \& \_$userid $=768492 \& \mathrm{md} 5=9 \mathrm{fb} 3 \mathrm{fa} 70 \mathrm{c} 1 \mathrm{abcf8c} 6 \mathrm{eb} 1 \mathrm{~d} 4 \mathrm{f} 14 \mathrm{ca} 882 \mathrm{a} 8>$.

${ }^{18}$ C.S. Karthikeyan, Katja Petera, Helga Wietascha and Mukundan Thelakkat. "Highly efficient solid-state dye-sensitized $\mathrm{TiO} 2$ solar cells via control of retardation of recombination using novel donor-antenna dyes." Solar Energy Materials and Solar Cells Volume 91, Issue 5, 6 March 2007, Pages 432-43919 May $2008<$ http://www.sciencedirect.com/science?_ob=ArticleURL\&_udi=B6V51-4MBC50X-

$3 \&$ _user $=768492 \&$ coverDate $=03 \% 2 \mathrm{~F} 06 \% 2 \mathrm{~F} 2007 \&$ alid $=741807035 \&$ rdoc $=48 \&$ fmt $=$ high $\&$ orig $=$ sea

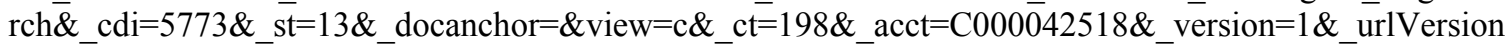
$=0 \& \_$userid $=768492 \& \mathrm{md} 5=7 \mathrm{ad} 6636577 \mathrm{~b} 64 \mathrm{ad} 30 \mathrm{~d} 9 \mathrm{e} 5 \mathrm{cde} 76 \mathrm{~b} 877 \mathrm{f} 8>$.

${ }^{19}$ Judit Ohlssona, Henriette Wolphera, Anders Hagfeldtb and Helena Grennberg, "New dyes for solar cells based on nanostructured semiconducting metal oxides Synthesis and characterisation of ruthenium(II) complexes with thiol-substituted ligands ." Journal of Photochemistry and Photobiology A: Chemistry Volume 148, Issues 1-3, 31 May 2002, Pages 41-4819 May 2008 $<$ http://www.sciencedirect.com/science?_ob=ArticleURL\&_udi=B6TGY-45BHH2J$1 \&$ user $=768492 \&$ _coverDate $=05 \% 2 \mathrm{~F} 31 \% 2 \mathrm{~F} 2002 \&$ alid $=741875432 \&$ rdoc $=547 \&$ fmt $=$ high\&_orig $=\mathrm{se}$ $\operatorname{arch} \& \_c d i=5267 \& \_s t=13 \&$ docanchor $=\&$ view $=c \& \_c t=633 \&$ acct $=C 000042518 \&$-version $=1 \&$ urlVersio $\mathrm{n}=0$ \&_userid $=768492 \& \mathrm{md} 5=\mathrm{d} 7632441 \mathrm{~d} 3 \mathrm{abf} 885 \mathrm{~b} 69 \mathrm{f} 5610 \mathrm{e} 3855 \mathrm{be} 5>$.

${ }^{20}$ Bandara, Jayasundera , and Hasitha Weerasinghe. "Design of high-efficiency solid-state dye-sensitized solar cells using coupled dye mixtures ." Hasitha Weerasinghe Volume 88, Issue 1, 15 June 2005, Pages 11019 May $2008<\mathrm{http} / /$ www.sciencedirect.com/science?_ob=ArticleURL\&_udi=B6V51-4DTKMM3-

$3 \&$ user $=768492 \&$ coverDate $=06 \% 2 \mathrm{~F} 15 \% 2 \mathrm{~F} 2005 \&$ alid $=741807035 \&$ rdoc $=93 \&$ fmt $=$ high\&_orig $=$ sea $\mathrm{rch} \&$ cdi $=5773 \&$ st $=13 \&$ docanchor $=\&$ view $=\mathrm{c} \& \_\mathrm{ct}=198 \& \_\mathrm{acct}=\mathrm{C} 000042518$ \&_version $=1 \&$ urlVersion $=0 \&$ userid $=768492 \& \mathrm{md} 5=18 \mathrm{a} 9955867 \mathrm{ae} 5658206 \mathrm{f} 43 \mathrm{eced} 9 \mathrm{c} 52 \mathrm{cf}>$.

${ }^{21}$ Perera, V. P. S., P. K. D. D. P. Pitigalaa, M. K. I. Senevirathnea and K. Tennakone. "A solar cell sensitized with three different dyes ." Solar Energy Materials and Solar Cells Volume 85, Issue 1, 1 January 2005, Pages 91-9819 May 2008<http://www.sciencedirect.com/science?_ob=ArticleURL\&_udi=B6V514CHS25B-

$3 \& \_u s e r=768492 \& \_$coverDate $=01 \% 2 \mathrm{~F} 01 \% 2 \mathrm{~F} 2005 \&$ alid $=741807035 \&$ rdoc $=115 \&$ fmt $=$ high \&_orig $=\mathrm{se}$ arch\&_cdi $=5773 \& \_s t=13 \&$ docanchor $=\&$ view $=$ c\&_ct $=198 \&$ acct $=$ C000042518\&_version $=1 \&$ urlVersio $\mathrm{n}=0$ \&_userid $=768492 \& \mathrm{md} 5=\mathrm{abc} 1 \mathrm{e} 953807 \mathrm{f} 661 \mathrm{c} 32 \mathrm{df0a98f7242 \textrm {eda } >}$. 
${ }^{22}$ Anders Hagfeldtt, and Michael Gratzel. "Light-Induced Redox Reactions in Nanocrystalline Systems." Chem, Rev. 1995, 95, 49-68 19 May $2008<$ http://pubs.acs.org/cgi-

bin/archive.cgi/chreay/1995/95/i01/pdf/cr00033a003.pdf $>$.

${ }^{23}$ Zerihun Kebede, and Sten-Eric Lindquist. "Donor-acceptor interaction between non-aqueous solvents and 2 to generate I-3, and its implication in dye sensitized solar cells." Solar Energy Materials and Solar Cells Volume 57, Issue 3, March 1999, Pages 259-275 20 May 2008

$<$ http://www.sciencedirect.com/science?_ob=ArticleURL\&_udi=B6V51-3VYYBN1-

$6 \& \_u s e r=768492 \&$ _coverDate $=03 \% 2 \mathrm{~F} 31 \% 2 \mathrm{~F} 1999 \&$ alid $=741875432 \&$ rdoc $=609 \&$ fmt $=$ high\&_orig $=\mathrm{se}$ $\operatorname{arch} \&$ cdi $=5773 \& \_$st $=13 \&$ docanchor $=\& v i e w=c \&$ ct $=633 \&$ acct $=C 000042518 \&$-version $=1 \&$ urlVersio $\mathrm{n}=0 \&$ _userid $=768 \overline{49} 2 \& \mathrm{md} \overline{5}=81 \mathrm{~d} 63090 \mathrm{a} 03 \mathrm{e} 241 \mathrm{c} 57 \overline{7} \mathrm{e} 2 \mathrm{~b} 4224 \overline{\mathrm{d}} 5 \mathrm{~b} 442>$.

${ }^{24}$ M.S. Akhtar, J.-M. Chun, H.-C. Lee, O.-B. Yang, Composite electrolyte of heteropolyacid (HPA) and polyethylene oxide (PEO) for solid-state dyesensitized solar cell, Electrochimica Acta (2007), doi:10.1016/j.electacta.2008.04.073.

${ }^{25}$ G. Katsarosa, T. Stergiopoulosa, I. M. Arabatzisa, K. G. Papadokostakia and P. Falaras, "A solvent-free composite polymer/inorganic oxide electrolyte for high efficiency solid-state dye-sensitized solar cells ." rnal of Photochemistry and Photobiology A: Chemistry Volume 149, Issues 1-3, 28 June 2002, Pages 19119820 May $2008<$ http://www.sciencedirect.com/science?_ob=ArticleURL\&_udi=B6TGY-459J643-

$1 \& \_$user $=768492 \&$ _coverDate $=06 \% 2 \mathrm{~F} 28 \% 2 \mathrm{~F} 2002 \&$ alid $=741875432 \&$ rdoc $=543 \&$ fmt $=$ high \&_orig $=\mathrm{se}$

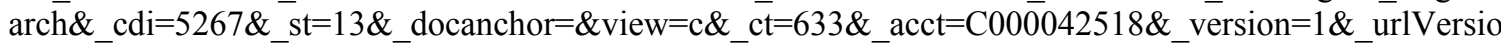
$\mathrm{n}=0 \&$ _userid $=768492 \& \mathrm{md} \overline{5}=\mathrm{f} 42431 \mathrm{c} 203 \mathrm{e} 3 \mathrm{f} 5 \mathrm{e} 14 \mathrm{fcffef} 07 \mathrm{dce} 7 \mathrm{~d} 960>$.

${ }^{26}$ Jing Zhang, Ying Yanga, Sujuan Wua, Sheng Xua, Conghua Zhoua, Hao Hua, Bolei Chena, Hongwei Hana and Xingzhong Zhao. "Improved photovoltage and performance by aminosilane-modified PEO/P(VDF-HFP) composite polymer electrolyte dye-sensitized solar cells ." Electrochimica Acta Volume 53, Issue 16, 30 June 2008, Pages 5415-542220 May 2008

$<$ http://www.sciencedirect.com/science?_ob=ArticleURL\&_udi=B6TG0-4S0YXRY-

$3 \&$ _user $=768492 \&$ _coverDate $=06 \% 2 \mathrm{~F} 30 \% 2 \mathrm{~F} 2008 \&$ alid $=742433512 \&$ rdoc $=5 \&$ fmt $=$ high $\&$ orig $=$ sear ch\&_cdi $=5240 \& \_$sort $=\mathrm{d} \& \_s t=13 \&$ docanchor $=$ \&_ct $=433 \&$ acct $=$ C000042518\&_version $=1 \&$ _urlVersion $=0 \& \_$userid $=768 \overline{4} 92 \& \mathrm{md} \overline{5}=\mathrm{ec} 1790 \overline{2} 7 \mathrm{fc} 1 \mathrm{cdb} 2506 \overline{8} 4354 \mathrm{e} 74990129>$.

${ }^{27}$ Ana F. Nogueira and Marco-A. De Paoli, "A dye sensitized TiO2 photovoltaic cell constructed with an elastomeric electrolyte ." Ana F. Nogueira and Marco-A. De Paoli Volume 61, Issue 2, 1 March 2000, Pages 135-141 20 May $2008<\mathrm{http}: / /$ www.sciencedirect.com/science?_ob=ArticleURL\&_udi=B6V513 YDGHCG-

$4 \& \_u s e r=768492 \& \_$coverDate $=03 \% 2 \mathrm{~F} 01 \% 2 \mathrm{~F} 2000 \&$ alid $=741875432 \&$ rdoc $=599 \&$ fmt $=$ high \&_orig $=\mathrm{se}$ $\operatorname{arch} \& \_c d i=5773 \& \_s t=13 \&$ docanchor $=\&$ view $=c \&$ ct $=633 \&$ acct $=C 000042518 \&$-version $=1 \&$ urlVersio $\mathrm{n}=0 \&$ _userid $=768 \overline{49} 2 \& \mathrm{md} \overline{5}=\mathrm{a} 179 \mathrm{a} 7 \mathrm{fc} 17904 \mathrm{ba} 1 \mathrm{~b} 6 \overline{43} \mathrm{bf} 12 \mathrm{ba} 6 \overline{\mathrm{b}} \mathrm{be} 9 \mathrm{e}>$.

${ }^{28}$ J.N. de Freitas, A. de Souza Gonc, alves, M.-A. De

Paoli, J.R. Durrant, A.F. Nogueira, The role of gel electrolyte composition in the

kinetics and performance of dye-sensitized solar cells, Electrochimica Acta (2007), doi:10.1016/j.electacta.2008.05.009.

${ }^{29}$ O. A. Ileperuma, M. A. K. L. Dissanayake, and S. . "Dye-sensitised photoelectrochemical solar cells with polyacrylonitrile based solid polymer electrolytes." Electrochimica Acta Volume 47, Issue 17, 5 July 2002, Pages 2801-2807 20 May $2008<$ http://www.sciencedirect.com/science?_ob=ArticleURL\&_udi=B6TG0$45 \mathrm{NPF} 27-$

$2 \& \_u s e r=768492 \&$ _coverDate $=07 \% 2 \mathrm{~F} 05 \% 2 \mathrm{~F} 2002 \&$ alid $=741875432 \&$ rdoc $=542 \&$ fmt $=$ high \&_orig $=\mathrm{se}$ $\operatorname{arch} \& \_c d i=5240 \& \_s t=13 \&$ docanchor $=\& v i e w=c \& \_c t=633 \&$ acct $=C 000042518 \&$-version $=1 \&$ urlVersio $\mathrm{n}=0$ \&_userid $=768 \overline{49} 2 \& \mathrm{md} \overline{5}=35 \mathrm{a} 3$ eee $53 \mathrm{cb} 7 \mathrm{a} 8 \mathrm{ce} 8 \mathrm{ca} \overline{6} 8 \mathrm{c} 274 \mathrm{~d} 1 \overline{9} 0981>$. 


\begin{abstract}
${ }^{30}$ Moon-Sung Kanga, Kwang-Soon Ahnb and Ji-Won Lee, "Quasi-solid-state dye-sensitized solar cells employing ternary component polymer-gel electrolytes." Journal of Power Sources Volume 180, Issue 2, 1 June 2008, Pages 896-901 20 May 2008

$<$ http://www.sciencedirect.com/science? ob=ArticleURL\& udi=B6TH1-4S33N60-

$2 \&$ user $=768492 \&$ coverDate $=06 \% 2 \mathrm{~F} 01 \% 2 \mathrm{~F} 2008 \&$ alid $=742433512 \&$ rdoc $=11 \&$ fmt $=$ high $\&$ orig $=$ sea rch\&_cdi $=5269 \& \_$sort $=$d\&_st $=13 \&$ docanchor $=\& \_c t=433 \&$ acct $=$ C000042518\&_version $=1 \&$ urlVersio $\mathrm{n}=0 \&$ \&userid $=768492 \& \mathrm{md} \overline{5}=8 \mathrm{af} 150331 \mathrm{bbfc} 1 \mathrm{fe} 0 \mathrm{c} 67 \mathrm{fdea} 5826119 \mathrm{~b}>$.

${ }^{31}$ Zhen Huang, Xizhe Liub, Kexin Lib, Dongmei Lib, Yanhong Luob, Hong Lib, , , Wenbo Songa, , , LiQuan Chenb and Qingbo Meng. "Application of carbon materials as counter electrodes of dye-sensitized solar cells ." Electrochemistry Communications Volume 9, Issue 4, April 2007, Pages 596-598 20 May $2008<$ http://www.sciencedirect.com/science?_ob=ArticleURL\&_udi=B6VP5-4MFCWC5$1 \& \_$user $=768492$ \&_coverDate $=04 \% 2 \mathrm{~F} 30 \% 2 \mathrm{~F} 2007 \&$ alid $=742509780 \&$ rdoc $=163 \&$ fmt $=$ high \&_orig $=\mathrm{se}$ arch\&_cdi $=6197 \&$ st $=13 \&$ docanchor $=\& v i e w=c \&$ ct $=504 \&$ acct $=C 000042518 \&$-version $=1 \&$ urlVersio $\mathrm{n}=0 \&$ \&userid $=768492 \& \mathrm{md} 5=4 \mathrm{e} 2 \mathrm{bb} 71 \mathrm{a} 52754 \mathrm{a} 17159 \mathrm{a} 6 \mathrm{~d} 1 \mathrm{e} 42 \mathrm{a} 54782>$.

${ }^{32}$ Won Jae Lee, Easwaramoorthi Ramasamya, Dong Yoon Leea and Jae Sung Song. "Performance variation of carbon counter electrode based dye-sensitized solar cell." Solar Energy Materials and Solar Cells Volume 92, Issue 7, July 2008, Pages 814-818 20 May 2008 $<$ http://www.sciencedirect.com/science?_ob=ArticleURL\&_udi=B6V51-4RWHGSY$1 \&$ user $=768492$ \&_coverDate $=07 \% 2 \mathrm{~F} 31 \% 2 \mathrm{~F} 2008 \&$ alid $=742508249 \&$ rdoc $=4 \&$ fmt $=$ high $\&$ orig $=$ sear $\mathrm{ch} \& \_\mathrm{cdi}=5773 \&$ _sort $=\mathrm{d} \& \_\mathrm{st}=13 \& \_$docanchor $=\& \_\mathrm{ct}=515 \& \_\mathrm{acct}=\mathrm{C} 000042518 \&$-version $=1 \&$ urlVersion $=0 \&$ userid $=768492 \& \mathrm{md} \overline{5}=1159893 \mathrm{f} 8 \mathrm{c} 2147202 \mathrm{a} \overline{7} 0 \mathrm{da} 665 \mathrm{de} 33 \mathrm{fe} 6>$.
\end{abstract}

${ }^{33}$ Seok-Soon Kima, Kyung-Won Parkb, Jun-Ho Yuma and Yung-Eun Sung, "Dye-sensitized solar cells with Pt-NiO and Pt-TiO2 biphase counter electrodes ." Journal of Photochemistry and Photobiology A: Chemistry Volume 189, Issues 2-3, 25 June 2007, Pages 301-306 20 May 2008 $<\mathrm{http}: / /$ www.sciencedirect.com/science?_ob=ArticleURL\&_udi=B6TGY-4N43RSX$4 \&$ user $=768492 \&$ coverDate $=06 \% 2 \mathrm{~F} 25 \% 2 \mathrm{~F} 2007 \&$ alid $=742509780 \&$ rdoc $=140 \&$ fmt $=$ high \& orig $=\mathrm{se}$ $\operatorname{arch} \& \_c d i=5267 \& \_s t=13 \& \_d o c a n c h o r=\& v i e w=c \& \_c t=504 \&$ acct $=C 000042518 \&$ version $=1 \&$ urlVersio $\mathrm{n}=0 \& \_$userid $=768492 \& \mathrm{md} 5=\mathrm{c} 3556280 \mathrm{f} 198668319 \mathrm{ae} 039 \mathrm{f} 75 \mathrm{~d} 0141 \mathrm{f}>$.

${ }^{34}$ Pinjiang Li, Jihuai Wu, Jianming Lina, Miaoliang Huanga, Zhan Lana and Qinghua Li. "Improvement of performance of dye-sensitized solar cells based on electrodeposited-platinum counter electrode."

Electrochimica Acta Volume 53, Issue 12, 1 May 2008, Pages 4161-4166 20 May 2008

$<\mathrm{http} / /$ www.sciencedirect.com/science? ob=ArticleURL\&_udi=B6TG0-4RHP9CM-

J\&_user $=768492 \&$ coverDate $=05 \% 2 \mathrm{~F} 01 \% 2 \mathrm{~F} 2008 \&$ _alid $=742508249 \&$ rdoc $=20 \&$ fmt $=$ high \&_orig $=$ sear $\mathrm{ch} \& \_$cdi $=5240 \&$ sort $=\mathrm{d} \& \_\mathrm{st}=13 \& \_$docanchor $=\& \_\mathrm{ct}=515 \&$ acct $=\mathrm{C} 000042518 \&$ \&ersion $=1 \&$ urlVersion $=0 \&$ userid $=768492 \& \mathrm{md} 5=9 \mathrm{dfea} 48 \mathrm{~b} 3868 \mathrm{bd} 61 \mathrm{bbeba2e} 78 \mathrm{~d} 5 \mathrm{a} 691 \mathrm{f}>$.

${ }^{35}$ Yongxiang Lia, Jürgen Hagena, Winfried Schaffrathb, Peter Otschikb and Dietrich Haarer, "Titanium dioxide films for photovoltaic cells derived from a sol-gel process ." Solar Energy Materials and Solar Cells Volume 56, Issue 2, 27 November 1998, Pages 167-174 21 May 2008

$<\mathrm{http}: / /$ www.sciencedirect.com/science?_ob=ArticleURL\&_udi=B6V51-3V6XK7K-

$6 \&$ user $=768492$ \&_coverDate $=11 \% 2 \mathrm{~F} 27 \% 2 \mathrm{~F} 1998 \&$ alid $=743097493 \&$ rdoc $=469 \&$ fmt $=$ high\&_orig $=\mathrm{se}$ $\operatorname{arch} \&$ cdi $=5773 \& \_s t=13 \& \_d o c a n c h o r=\& v i e w=c \& \_c t=495 \& \_a c c t=C 000042518 \&$ version $=1 \&$ urlVersio

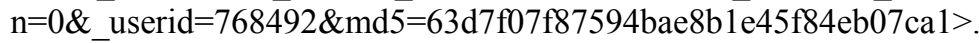

${ }^{36}$ Seigo Ito, Takurou N. Murakami, Pascal Comte, Paul Liska, Carole Grätzel, Mohammad K. Nazeeruddin, and Michael Grätzel. "Fabrication of thin film dye sensitized solar cells with solar to electric power conversion efficiency over 10\% ." Thin Solid Films Volume 516, Issue 14, 30 May 2008, Pages 4613-4619 21 May $2008<$ http://www.sciencedirect.com/science?_ob=ArticleURL\&_udi=B6TW04NYSXBV-

X\&_user $=768492 \&$ coverDate $=05 \% 2 F 30 \% 2 F 2008 \&$ alid $=743097493 \&$ rdoc $=13 \&$ fmt $=$ high \&_orig $=$ sea 
rch\&_cdi $=5548 \&$ sort $=$ d\&_st $=13 \& \_d o c a n c h o r=\& \_c t=495 \& \_$acct $=$C000042518\&_version $=1 \&$ urlVersio $\mathrm{n}=0 \& \_$userid $=768492 \& \mathrm{md} \overline{5}=8 \mathrm{fbcab} 281 \mathrm{f190fe} 84$ eada57599a $65683>$.

${ }^{37}$ Songyuan Dai, Jian Wenga, Yifeng Suia, Shuanghong Chena, Shangfeng Xiaoa, Yang Huanga, Fantai Konga, Xu Pana, Linhua Hua, Changneng Zhanga and Kongjia Wang, "The design and outdoor application of dye-sensitized solar cells." Inorganica Chimica Acta Volume 361, Issue 3, 15 February 2008, Pages 786-

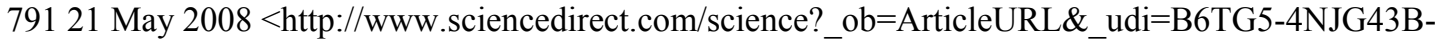
$2 \& \_$user $=768492 \&$ _coverDate $=02 \% 2 \mathrm{~F} 15 \% 2 \mathrm{~F} 2008 \& \_$alid $=743097493 \& \_$rdoc $=58 \&$ fmt $=$ high $\&$ orig $=$ sea rch\&_cdi $=5245 \& \_$sort $=\mathrm{d} \& \_\mathrm{st}=13 \&$ docanchor $=\& \_\mathrm{ct}=495 \&$ acct $=\mathrm{C} 000042518 \&$ \&ersion $=1 \&$ urlVersio $\mathrm{n}=0 \& \_$userid $=768492 \& \mathrm{md} \overline{5}=28313 \mathrm{e} 3 \mathrm{afd} 233 \mathrm{f} 13 \mathrm{~b} 3 \mathrm{~b} 6186375 \mathrm{fb} 012 \mathrm{f}>$.

${ }^{38}$ Murakoshi, Kei, Gentaro, and Kano, et al. "Importance of binding states between photosensitizing molecules and the TiO 2 surface for efficiency in a dye-sensitized solar cell." Journal of Electroanalytical Chemistry 396(1995): 27-34.

${ }^{39}$ Veronica Czitrom, "One-Factor-at-a-Time Versus Designed Experiments." The American Statistician Vol. 53, No. 2(May 1999): 126-131.

${ }^{40}$ MAN SOLAR B.V., "Working Principle Of Dye Sensitized Solar Cells." Technology. Mansolar. 14 May $2008<$ http://www.mansolar.com/function.htm>.

${ }^{41}$ Grätzel, Micheal. "Dye-sensitized solar cells ." Journal of Photochemistry and Photobiology C:

Photochemistry Reviews Vol 4. Issue 231 October 2003 Pages 145-153 . 14 May 08

$<$ http://www.sciencedirect.com/science?_ob=ArticleURL\&_udi=B6W79-49MDXVF-

$1 \& \_$user $=768492 \&$ _coverDate $=10 \% 2 \mathrm{~F} 31 \% 2 \mathrm{~F} 2003 \&$ alid $=739597814 \&$ rdoc $=1 \&$ fmt $=$ high \&_orig $=$ sear ch\&_cdi $=6621 \& \_s t=13 \&$ docanchor $=$ \&_ct $=2 \& \_$acct $=$C $000042518 \&$ version $=1 \&$ urlVersion $=0$ \&_userid $=768492 \& \mathrm{md} 5=188 \mathrm{~b} 05214 \mathrm{dc} 532 \mathrm{a} 0763 \mathrm{ef} 5 \mathrm{~d} 1 \mathrm{~d} 3311 \mathrm{a} 5 \mathrm{c}>$.

${ }^{42}$ Montgomery, Douglas. Design and Analysis of Experiments. 6th . Hoboken, NJ: John Wiley and Sons, 2005 .

${ }^{43}$ Antonine, James. "Solar Cells and Electrical Circuits." Antonine Education. May, 2008. Antonine Education Website. 23 Jul $2008<$ http://www.antonine-education.co.uk/New_items/SPC/Circuits.htm>. 